Melting of Newly Formed Mafic Crust for the Formation of Neoproterozoic I-Type Granite in the Hannan Region, South China

Author(s): Jun-Hong Zhao and Mei-Fu Zhou

Source: The Journal of Geology, Vol. 117, No. 1 (January 2009), pp. 54-70

Published by: The University of Chicago Press

Stable URL: http://www.jstor.org/stable/10.1086/593321

Accessed: 21/01/2011 03:03

Your use of the JSTOR archive indicates your acceptance of JSTOR's Terms and Conditions of Use, available at http://www.jstor.org/page/info/about/policies/terms.jsp. JSTOR's Terms and Conditions of Use provides, in part, that unless you have obtained prior permission, you may not download an entire issue of a journal or multiple copies of articles, and you may use content in the JSTOR archive only for your personal, non-commercial use.

Please contact the publisher regarding any further use of this work. Publisher contact information may be obtained at http://www.jstor.org/action/showPublisher?publisherCode=ucpress.

Each copy of any part of a JSTOR transmission must contain the same copyright notice that appears on the screen or printed page of such transmission.

JSTOR is a not-for-profit service that helps scholars, researchers, and students discover, use, and build upon a wide range of content in a trusted digital archive. We use information technology and tools to increase productivity and facilitate new forms of scholarship. For more information about JSTOR, please contact support@jstor.org. 


\title{
Melting of Newly Formed Mafic Crust for the Formation of Neoproterozoic I-Type Granite in the Hannan Region, South China
}

\author{
Jun-Hong Zhao and Mei-Fu Zhou ${ }^{1}$ \\ State Key Lab of Ore Deposit Geochemistry, Institute of Geochemistry, Chinese Academy of Sciences, \\ Guiyang 550002, China; and Department of Earth Sciences, University of Hong Kong, Hong Kong \\ (e-mail: zhao-junhong@hotmail.com)
}

\begin{abstract}
A B S T R A C T
Neoproterozoic magmatism in the Hannan region at the northwestern margin of the Yangtze Block is characterized by numerous felsic plutons associated with minor mafic-ultramafic intrusions. The felsic plutons are either adakitic or normal-arc granitic in composition. The adakitic plutons are $\sim 735 \mathrm{Ma}$ in age and are interpreted as having formed by partial melting of a thickened lower mafic crust. Among the normal-arc-related felsic plutons, the Tianpinghe pluton is the largest and has a SHRIMP zircon U-Pb age of $762 \pm 4 \mathrm{Ma}$, older than the adakitic plutons in the region. Rocks from the Tianpinghe pluton have relatively high $\mathrm{SiO}_{2}(67.1-70.1 \mathrm{wt} \%)$ and $\mathrm{K}_{2} \mathrm{O}+\mathrm{Na}_{2} \mathrm{O}(7.8-8.6 \mathrm{wt} \%)$ and relatively low $\mathrm{MgO}(0.7-1.3 \mathrm{wt} \%)$ and $\mathrm{Al}_{2} \mathrm{O}_{3}$ contents (14.5-15.6 wt \%), with $\mathrm{Al}_{2} \mathrm{O}_{3} /\left(\mathrm{CaO}+\mathrm{K}_{2} \mathrm{O}+\mathrm{Na}_{2} \mathrm{O}\right)(\mathrm{A} / \mathrm{CNK})$ values ranging from 0.95 to 1.08. They have arc-affinity trace-element compositions that are characterized by enrichment of large-ion lithophile elements and depletion of high-field-strength elements $(\mathrm{Nb}, \mathrm{Ta})$, with strong positive $\mathrm{Pb}$ and negative Ti anomalies. They have a narrow range of $\varepsilon \mathrm{Nd}(t)$ values $(+0.15$ to -1.76$)$ and relatively high zircon $\varepsilon \mathrm{Hf}$ values $(+0.6$ to +8.3 ). These geochemical features are typical of I-type granites. The rocks from the Tianpinghe pluton have relatively young single-stage and two-stage Hf model ages (1.01-1.31 and 1.31-2.01 Ga, respectively), suggesting that the pluton was generated by partial melting of newly formed basaltic rocks. On the basis of its arc-related geochemical affinity and its emplacement before voluminous adakitic magmatism but after mafic-ultramafic intrusions, the Tianpinghe pluton is considered to be Neoproterozoic arc granite formed during a period of crustal growth and reworking. Generation of the later adakitic plutons suggests that the crustal thickness increased to more than $50 \mathrm{~km}$ by mafic magma underplating.
\end{abstract}

Online enhancements: color figures, tables.

\section{Introduction}

Calc-alkaline granitoids are the most abundant rock types in orogenic belts and can provide valuable information about the processes of continental crustal evolution and differentiation (e.g., Roberts et al. 2000; Ortega-Obregon et al. 2003; Kemp et al. 2007). I-type calc-alkaline granitoids can be produced by melting of newly formed lower crust, fractional crystallization of mantle-derived mafic magmas, or mixing of mantle-derived magmas and continental felsic melts (e.g., Juster et al. 1989; Singer et al. 1992; Rudnick 1995; Soesoo 2000; Rajesh 2004; Cluzel et al. 2005; Kemp et al. 2007). Thus, I-type calc-alkaline granitoids may provide information about the interaction between

\footnotetext{
Manuscript received March 28, 2008; accepted July 29, 2008.

${ }^{1}$ Department of Earth Sciences, University of Hong Kong, Hong Kong.
}

the mantle and the overlying continental crust (e.g., Kemp et al. 2007). In addition, they can be used to discriminate tectonic settings and can help decipher the secular evolution of the continental crust (e.g., Pitcher 1993; Frost et al. 2001).

The Yangtze Block in South China, which is considered part of the supercontinent Rodinia ( $\mathrm{Li}$ et al. 1995), is characterized by numerous Neoproterozoic I-type granitic plutons, with minor S-type granitic and mafic plutons along its western margin (e.g., Ling et al. 2001; Zhou et al. 2002a, 2002b, 2006a, 2006b; Li et al. 2003; Zhao and Zhou 2007a, $2007 b, 2008 a, 2008 b$ ). Although their petrogenesis is not clear and remains controversial, the I-type granites are important for understanding the crustmantle interaction, continental crustal growth, and reworking of the Yangtze Block. The most interesting problem in the region is the heat source neces- 
sary for the formation of these plutons. Li et al. (2003) proposed that the felsic rocks were generated by an upwelling mantle plume; however, Zhou et al. (2002a) argued that they were formed at an active continental margin.

Numerous Neoproterozoic mafic-ultramafic, adakitic, and normal-arc-related felsic plutons crop out in the Hannan region, on the northwestern margin of the Yangtze Block (fig. 1). The maficultramafic plutons are documented to have been produced by partial melting of lithospheric mantle above a subduction zone (Zhou et al. 2002a; Zhao and Zhou 2008b). The subsequent formation of the adakitic plutons probably reflects melting of a thickened lower crust (Zhao and Zhou 2008a). The normal-arc-related granitic plutons have not been examined in detail. This study focuses on the Tianpinghe pluton, the largest normal-arc-related felsic pluton in the region. As a representative example of arc-related magmatism, it is important for understanding the growth and reworking of continental crust in the region and for determining the tectonic setting in which it was emplaced along the northwestern margin of the Yangtze Block.

\section{Geological Background}

South China consists of the Yangtze Block to the northwest and the Cathaysia Block to the southeast (fig. 1), which were welded together during Meso- to Neoproterozoic time (Chen et al. 1991; Li and McCulloch 1996; Wang et al. 2007). The Yangtze Block is bounded by the eastern Tibetan Plateau to the west and is separated from the North China Block by the Qinling-Dabie orogenic belt, which was formed by closure of the easternmost part of Paleotethys (Mattauer et al. 1985; Hsü et al. 1987).

The Yangtze Block consists of Archean to Neoproterozoic basement complexes overlain by a Sinian to Cenozoic cover sequence. The basement complexes consist of arenaceous to argillaceous sedimentary strata that have been metamorphosed to low-grade greenschist facies assemblages. The Archean Kongling Terrane in the Yangtze Block consists of felsic gneisses, clastic metasedimentary rocks, and amphibolites (Gao et al. 1999). Mesoproterozoic rocks are also preserved along the margins of the Yangtze Block (Greentree et al. 2006; Li et al. 2007). The Neoproterozoic sequences along the western margin of the Yangtze Block consist of a lower sequence of volcanic rocks overlain by a thick

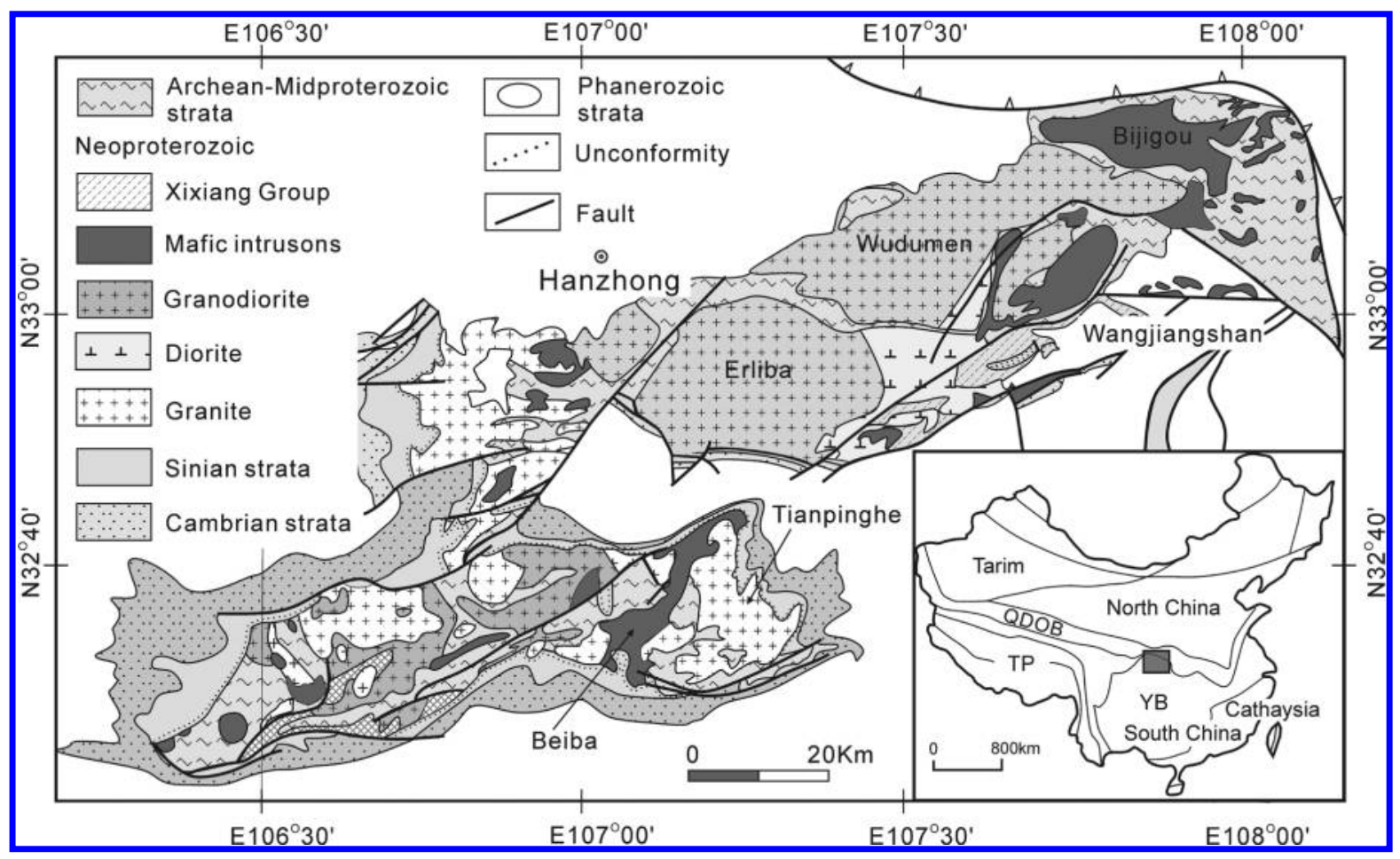

Figure 1. Simplified geological map showing the distribution of Neoproterozoic plutons in the Hannan region at the northwestern margin of the Yangtze Block, South China (modified from BGMRS 1990). YB= Yangtze Block; $T P=$ Tibetan Plateau; $Q D O B=$ Qinglin-Dabie orogenic belt. 
flysch sequence (Yan et al. 2004; Zhou et al. 2006b). The thick cover sequence $(>9 \mathrm{~km})$ of upper Sinian to Permian strata consists of glacial deposits and clastic, carbonate, and metavolcanic rocks (Yan et al. 2003).

Neoproterozoic magmatism in South China is characterized by numerous granitic plutons, with less abundant mafic-ultramafic plutons. Both the mafic-ultramafic and the felsic plutons intrude Mesoproterozoic rocks and are unconformably overlain by Sinian strata (Zhou et al. 2002a, 2002b; Li et al. 2003; Zhou et al. 2006a, 2006b; Zhao and Zhou 2007a, 2007b).

In the Hannan region on the northwestern margin of the Yangtze Block (fig. 1), pre-Sinian (>750 Ma) rocks are exposed in a belt more than $1200 \mathrm{~km}$ long (Zhang 1991) and are divided into three tectonostratigraphic units: from the base upward, the Houhe complex, the Huodiya Group, and the Xixiang Group (Ling et al. 2003).

The Archean-Paleoproterozoic Houhe complex consists of trondhjemitic gneisses, amphibolites, and migmatites, with minor marbles. The Mesoto Neoproterozoic Huodiya Group unconformably overlies the Houhe complex and consists of metasedimentary rocks in the lower part and volcanic rocks in the upper part. The Neoproterozoic Xixiang Group is a metavolcanic-sedimentary succession with a total thickness of more than $4 \mathrm{~km}$. It comprises a lower unit dominated by high-Mg andesite and low-Ti tholeiitic basalts and an upper unit composed of basalt, andesite, and daciterhyolite with arclike geochemical characteristics (Gao et al. 1990; Ling et al. 2003). The lower and upper units of the Xixiang Group have zircon U-Pb ages of 950 and $895 \mathrm{Ma}$, respectively (Ling et al. 2003).

Many Neoproterozoic plutons in the Hannan region intrude the Archean to Mesoproterozoic strata and are unconformably overlain by unmetamorphosed Sinian strata, which are in turn overlain by Paleozoic strata (fig. 1). These plutons include mafic-ultramafic, adakitic, and normal-arc granitic plutons. The 820-Ma Wangjiangshan, 782-Ma Bijigou, and 814-Ma Beiba mafic-ultramafic intrusions form a $100-\mathrm{km}$-long belt from northeast to southwest (Zhao and Zhou 2008b). Adakitic plutons include the Wudumen and Erliba granodioritic plutons, which occur in the northeastern part of the region and have SHRIMP zircon U-Pb ages of $735 \pm$ $8 \mathrm{Ma}$ and $730 \pm 6 \mathrm{Ma}$, respectively (Zhao and Zhou 2008a). Normal-arc granitic plutons occur as stocks mainly in the southwestern part of the Hannan region (fig. 1). The Tianpinghe pluton, one of the largest arc granitic plutons, was overlain by Sinian strata to the east and emplaced into the Beiba intrusion to the west (fig. 1; BGMRS 1989). Although Ling et al. (2006) reported a laser inductively coupled plasma-mass spectrometry (ICP-MS) ${ }^{206} \mathrm{~Pb} /{ }^{238} \mathrm{U}$ age of $863 \pm 10 \mathrm{Ma}$, interpreted as the crystallization age, these age data are inconsistent with the field relationships, which show that the Tianpinghe pluton is younger than the 814-Ma Beiba intrusion.

\section{Petrography}

The Tianpinghe pluton consists of coarsegrained granites composed of alkali feldspar (mode $50 \%-55 \%$ ), quartz (mode $30 \%-35 \%$ ), plagioclase (mode 10\%), and biotite (mode 10\%). The alkali feldspar is mainly microcline, which forms anhedral, commonly embayed crystals up to $1.5 \times$ $5 \mathrm{~mm}$. Quartz is interstitial and fine grained, with a diameter generally less than $0.5 \mathrm{~mm}$ (rarely up to 1 $\mathrm{mm}$ ). Plagioclase forms small, irregular grains. Biotite is the only mafic mineral present and generally forms small aggregates, but a few inclusions of biotite may also occur in the microcline. Common accessory minerals include titanite, magnetite, and zircon. Samples show only slight alteration, with minor amounts of carbonate, kaolinite, and chlorite.

\section{Analytical Results}

SHRIMP Zircon U-Pb Dating. The results of SHRIMP U-Pb zircon analyses are listed in table 1. Sample TPH14, a granite from the Tianpinghe pluton, contains euhedral, oscillatory-zoned, igneous zircons with variable $U$ contents. The majority of the zircons have cores, patches, and thin rim overgrowths with high $U$, generally $>250 \mathrm{ppm}$. A small proportion of zircons with similar crystal morphology $(<10 \%)$ have lower $U$ concentrations $(<150 \mathrm{ppm})$. The high-U zircons give relatively young ${ }^{206} \mathrm{~Pb} /{ }^{238} \mathrm{U}$ ages and appear to have suffered minor $\mathrm{Pb}$ loss. Analyses of spots TPH14-01 and TPH14-02 were not used because the analytical spots overlapped high-common- $\mathrm{Pb}$ inclusions. Eight low-U zircons, which form a coherent group on the concordia diagram, have a weighted mean ${ }^{206} \mathrm{~Pb} /{ }^{238} \mathrm{U}$ age of $762 \pm 4 \mathrm{Ma}$, which we interpret as the crystallization age of the intrusion (fig. 2).

Major and Trace Elements. On the basis of CIPW normative mineralogy, rocks from the Tianpinghe pluton fall mainly in the granodiorite field in the QAP diagram, whereas they all lie in the granite field in the Ab-An-Or diagram. In the plot of total alkaline versus $\mathrm{SiO}_{2}$ (fig. 3a), rocks from the Tianpinghe pluton plot in the same classification fields 
Table 1. SHRIMP Zircon U-Pb Analytical Results for the Tianpinghe Pluton in Hannan Region, South China

\begin{tabular}{|c|c|c|c|c|c|c|c|}
\hline \multirow[b]{2}{*}{ Spot } & \multicolumn{3}{|c|}{ Concentration (ppm) } & \multirow[b]{2}{*}{${ }^{232} \mathrm{Th} /{ }^{238} \mathrm{U} \pm 1 \delta$} & \multicolumn{3}{|c|}{ Age \pm 1 SE $(\mathrm{Ma})$} \\
\hline & Common ${ }^{206} \mathrm{~Pb}$ & $\mathrm{U}$ & Radiogenic ${ }^{206} \mathrm{~Pb}$ & & ${ }^{206} \mathrm{~Pb} /{ }^{238} \mathrm{U}$ & ${ }^{207} \mathrm{~Pb} /{ }^{206} \mathrm{~Pb}$ & Discordant \\
\hline TPH14-01 & 15.76 & 278 & 20.4 & $.577 \pm .3$ & $528 \pm 7.1$ & $-79 \pm 877$ & \\
\hline ТPH14-02 & 33.17 & 259 & 29.1 & $.773 \pm .2$ & $794 \pm 33.2$ & $387 \pm 2104$ & \\
\hline TPH14-03 & $\ldots$ & 86 & 9.29 & $.987 \pm .4$ & $762 \pm 4.4$ & $791 \pm 33$ & 4 \\
\hline TPH14-07 & $\ldots$ & 473 & 48.9 & $1.046 \pm .2$ & $733 \pm 3.0$ & $740 \pm$ & 1 \\
\hline TPH14-08 & .2 & 69 & 7.54 & $.806 \pm .4$ & $774 \pm 5.6$ & $780 \pm$ & 1 \\
\hline ТPH14-16 & 0 & 279 & 28.9 & $.703 \pm .2$ & $733 \pm 3.3$ & $798 \pm$ & 9 \\
\hline ТPH14-18 & .28 & 118 & 12.7 & $.674 \pm .3$ & $756 \pm 4.4$ & $671 \pm$ & -14 \\
\hline TPH14-19 & .04 & 119 & 12.9 & $.631 \pm .3$ & $761 \pm 4.2$ & $761 \pm$ & 0 \\
\hline TPH14-22 & 1.24 & 386 & 38.5 & $.984 \pm .2$ & $708 \pm 3.6$ & $666 \pm$ & -7 \\
\hline TPH14-27 & $\ldots$ & 83 & 8.98 & $.592 \pm .4$ & $765 \pm 4.7$ & $789 \pm$ & 3 \\
\hline ТPH14-29 & .21 & 300 & 32.2 & $.637 \pm .2$ & $760 \pm 3.4$ & $718 \pm$ & -6 \\
\hline ТPH14-30 & .02 & 371 & 37.6 & $.922 \pm .2$ & $720 \pm 3.1$ & $780 \pm$ & 8 \\
\hline ТPH14-31 & $\ldots$ & 384 & 38.3 & $.709 \pm .2$ & $708 \pm 3.1$ & $778 \pm$ & 10 \\
\hline TPH14-35 & $\ldots$ & 174 & 18.6 & $2.393 \pm .3$ & $759 \pm 3.8$ & $762 \pm$ & 0 \\
\hline ТPH14-40 & $\ldots$ & 43 & 4.7 & $.634 \pm .6$ & $772 \pm 6.2$ & $731 \pm$ & -6 \\
\hline
\end{tabular}

Note. Sample TPH14 (a granite from the Tianpinghe pluton) was used.

as quartz monzonite and granite. The Tianpinghe granites are alkali-calcic in composition, according to the classification scheme of Frost et al. (2001; fig. $3 b$ ). They are also metaluminous, with an alumina saturation index (ASI; molar $\mathrm{Al}_{2} \mathrm{O}_{3}$ / $\left.\left(\mathrm{CaO}+\mathrm{Na}_{2} \mathrm{O}+\mathrm{K}_{2} \mathrm{O}\right)\right)$ ranging from 0.95 to 1.08 . The rocks from the Tianpinghe pluton range in $\mathrm{SiO}_{2}$ from 67.1 to $70.1 \mathrm{wt} \%$, in $\mathrm{MgO}$ from 0.67 to $1.25 \mathrm{wt} \%$, and in $\mathrm{Al}_{2} \mathrm{O}_{3}$ from 14.5 to $15.6 \mathrm{wt} \%$. They have high $\mathrm{K}_{2} \mathrm{O}(3.2-4.1 \mathrm{wt} \%)$ and $\mathrm{Na}_{2} \mathrm{O}(4.2-$ $5.2 \mathrm{wt} \%$ ) contents, giving low $\mathrm{K}_{2} \mathrm{O} / \mathrm{Na}_{2} \mathrm{O}$ ratios ranging from 0.64 to $0.99 . \mathrm{Fe}_{2} \mathrm{O}_{3}, \mathrm{MgO}, \mathrm{Al}_{2} \mathrm{O}_{3}, \mathrm{CaO}$, $\mathrm{TiO}_{2}$, and $\mathrm{P}_{2} \mathrm{O}_{5}$ all correlate negatively with $\mathrm{SiO}_{2}$.

All of the analyzed rocks have slightly U-shaped chondrite-normalized rare earth element (REE)

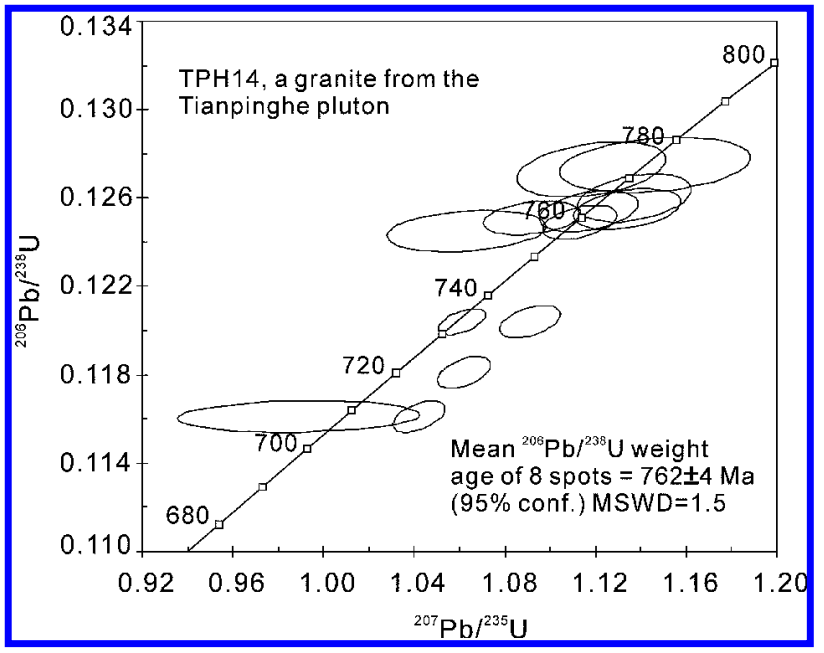

Figure 2. SHRIMP zircon U-Pb concordia plot for the Tianpinghe pluton in the Hannan region, South China. patterns with strong enrichment in light REEs (LREEs) and display slightly negative Eu anomalies $\left(\mathrm{Eu} / \mathrm{Eu}^{*}=0.73-0.95\right.$; fig. $\left.4 a\right)$. All of the samples also have a relatively narrow range of $(\mathrm{La} / \mathrm{Yb})_{\mathrm{N}}$ ratios (11.8-16.5). In primitive-mantle-normalized traceelement diagrams, the rocks show enrichment of large-ion lithophile elements $(\mathrm{Rb}, \mathrm{Ba}, \mathrm{Th}$, and $\mathrm{U})$ and depletion of $\mathrm{Nb}$ and $\mathrm{Ta}$, with negative $\mathrm{Ti}$ and positive $\mathrm{Pb}$ and $\mathrm{Zr}$-Hf anomalies (fig. $4 b$ ). They have low Sr (204-328 ppm) and high Y (14.7-22.3 ppm) concentrations, yielding low $\mathrm{Sr} / \mathrm{Y}$ ratios of 11.120.7. Compatible trace elements, such as $\mathrm{Cr}, \mathrm{Ni}$, and $\mathrm{V}$, are relatively low in abundance (table 2, available in the online edition or from the Journal of Geology office).

Whole-Rock Sr-Nd Isotopes. Rocks from the Tianpinghe pluton have low and constant initial ${ }^{87} \mathrm{Sr} /{ }^{86} \mathrm{Sr}$ ratios ranging from 0.7037 to 0.7053 and constant but slightly negative $\varepsilon \mathrm{Nd}$ values $(+0.15$ to -1.76 ; table 3). In the diagram of initial ${ }^{87} \mathrm{Sr} /{ }^{86} \mathrm{Sr}$ versus $\varepsilon \mathrm{Nd}(t)$, the samples plot near the mantle array (fig. 5). Their $\varepsilon \mathrm{Nd}(t)$ values are slightly lower than those of the Neoproterozoic mafic-ultramafic intrusions in the Hannan region (figs. 5, 6).

Zircon Lu-Hf Isotopes. Lu-Hf isotope analyses of zircons from four granite samples are presented in table 4, available in the online edition or from the Journal of Geology office, and are plotted in figures 7 and 8. Grain TPH14-19 has extremely low ${ }^{176} \mathrm{Lu} /{ }^{177} \mathrm{Hf} \quad(0.000778)$ and ${ }^{176} \mathrm{Hf} /{ }^{177} \mathrm{Hf}$ ratios $(0.281718)$, yielding a very low $\varepsilon \mathrm{Hf}$ value of -20.9 , different from those of the other analyses (figs. 7, 8). It is characterized by very old single-stage (2.14-Ga) and two-stage (3.92-Ga) model ages. The other analyses yielded ${ }^{176} \mathrm{Lu} /{ }^{177} \mathrm{Hf}$ ratios ranging from 

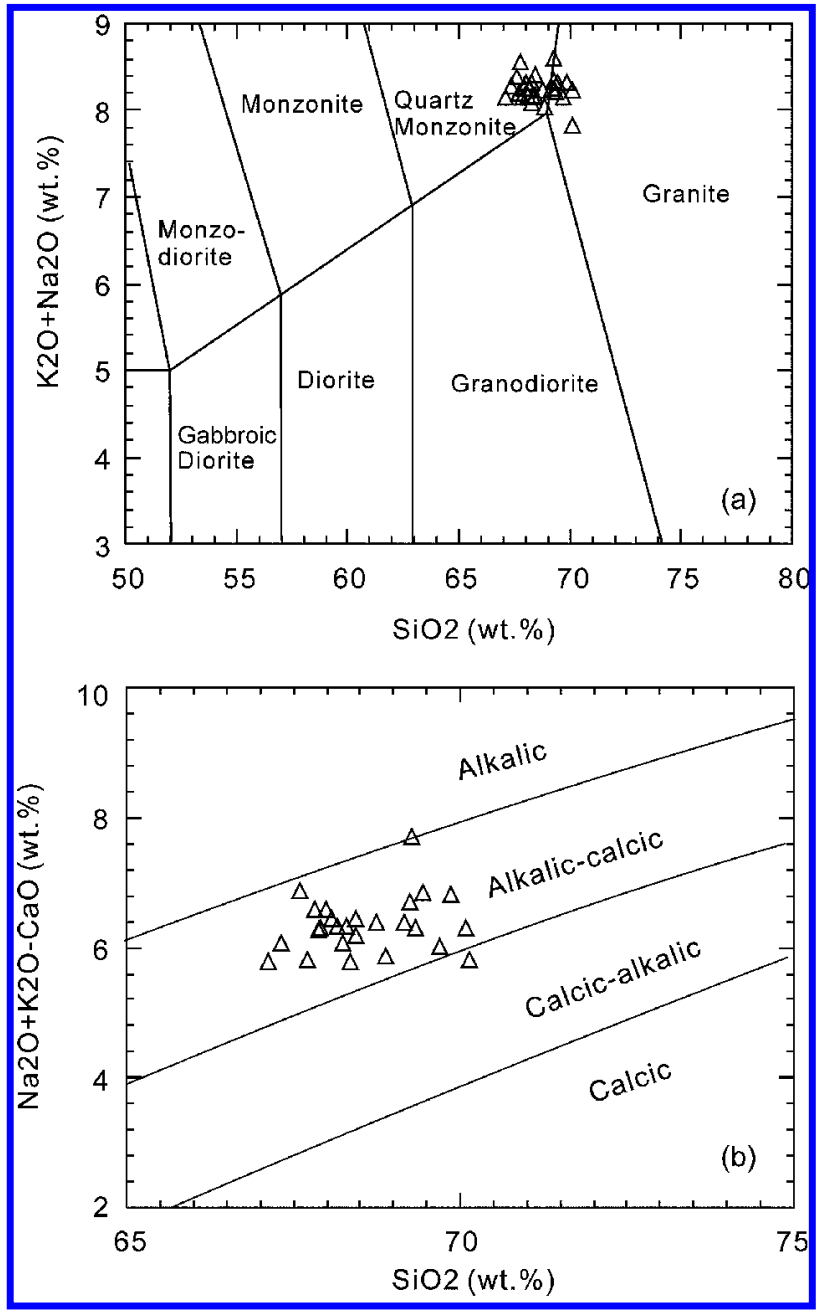

Figure 3. Total alkalis versus $\mathrm{SiO}_{2}$ (Middlemost 1994; a) and $\mathrm{Na}_{2} \mathrm{O}+\mathrm{K}_{2} \mathrm{O}-\mathrm{CaO}$ versus $\mathrm{SiO}_{2}$ (Frost et al. 2001; b) for the rocks from the Tianpinghe pluton in the Hannan region, South China.

0.000977 to 0.003058 and present-day ${ }^{176} \mathrm{Hf} /{ }^{177} \mathrm{Hf}$ ratios ranging from 0.282334 to 0.282575 (79 points). Initial ${ }^{176} \mathrm{Hf} /{ }^{177} \mathrm{Hf}$ ratios vary from 0.282314 to 0.282532 , with an average of 0.282412 (fig. 7, top). The $\varepsilon \mathrm{Hf}$ values range from +0.6 to +8.3 , with an average of 4.1. Single-stage model ages range from 1.01 to $1.31 \mathrm{Ga}$ and two-stage model ages from 1.31 to $2.01 \mathrm{Ga}$. The weighted means of the single-stage and two-stage model ages are $1.17 \pm 0.01$ and $1.74 \pm 0.07 \mathrm{Ga}$, respectively (fig. 7, bottom).

\section{Discussion}

Classification of the Tianpinghe Pluton as an I-Type Granitoid. Granitoids were originally divided into I- and S- type granites (White and Chappell
1983), which are different in petrography and geochemical composition (e.g., Collins et al. 1982; White and Chappell 1983). I-type granites normally have high $\mathrm{Na}_{2} \mathrm{O}$ and $\mathrm{CaO}$ and low $\mathrm{K}_{2} \mathrm{O}$ and alumina saturation (A/CNK) compared to S-type granites (Chappell and White 2001). In addition, I-type granites display more regular compositional variations than S-type granites because of their relatively homogeneous source regions (Chappell and White 2001).

Rocks from the Tianpinghe pluton form relatively linear trends in compositional-variation diagrams. They have moderate $\mathrm{Na}_{2} \mathrm{O}$ and $\mathrm{K}_{2} \mathrm{O}$ contents, with high $\mathrm{Na}_{2} \mathrm{O}+\mathrm{K}_{2} \mathrm{O}$ contents and low $\mathrm{K}_{2} \mathrm{O} / \mathrm{Na}_{2} \mathrm{O}$ ratios (table 2). The rocks are metaluminous, with $\mathrm{A} / \mathrm{CNK}$ ranging from 0.95 to 1.08

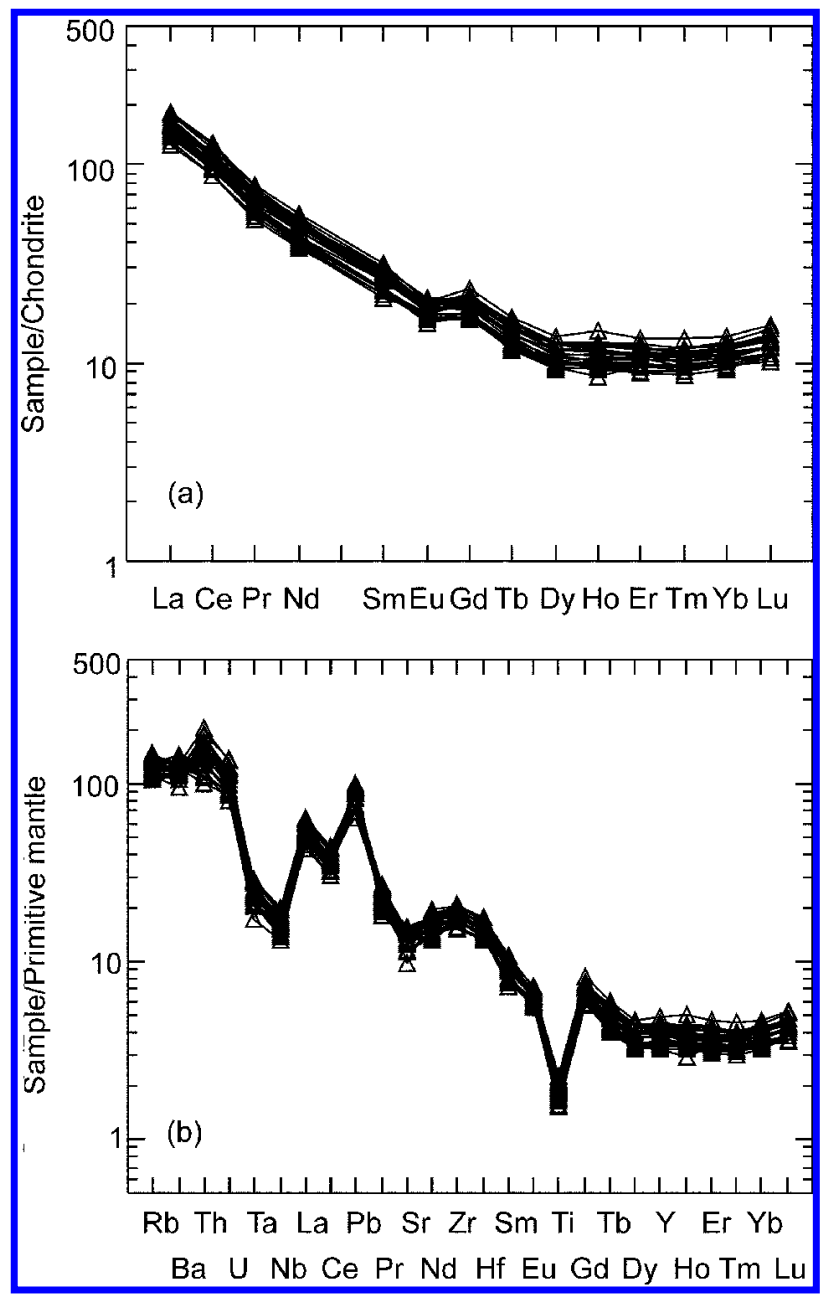

Figure 4. Chondrite-normalized rare earth element patterns $(a)$ and primitive-mantle-normalized trace-element patterns $(b)$ for the rocks from the Tianpinghe pluton in the Hannan region, South China. Normalizing values are from Sun and McDonough (1989). 


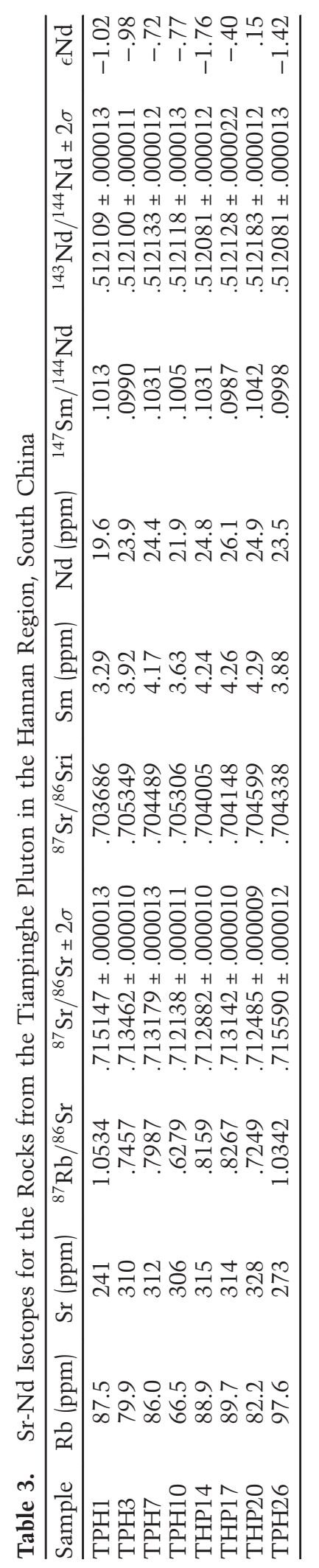




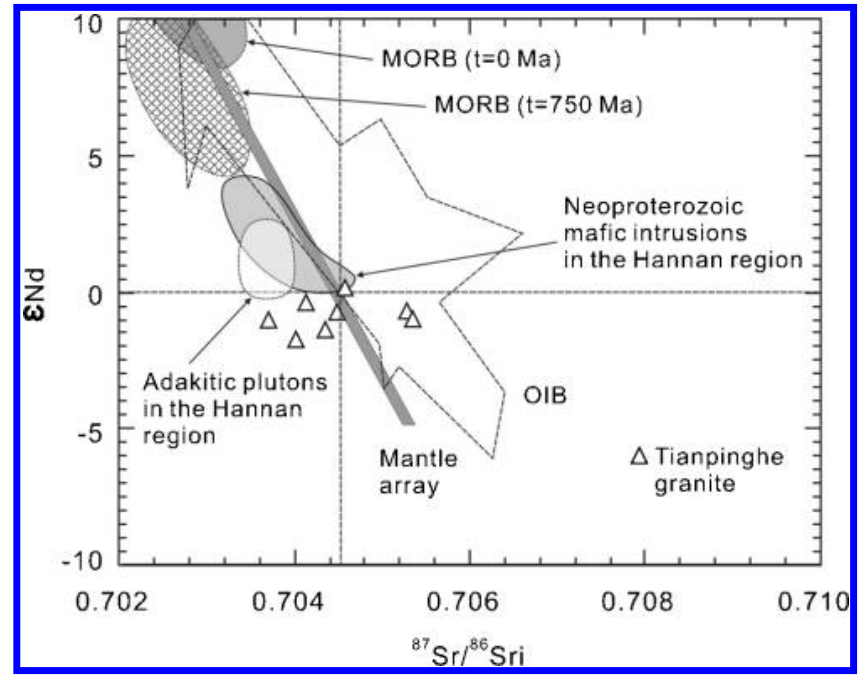

Figure 5. Sr-Nd isotopes for rocks from the Tianpinghe pluton. The fields for mid-ocean ridge basalt $(M O R B)$ and corrected MORB ( $T=750 \mathrm{Ma})$ are from Zimmer et al. (1995), and those for oceanic island basalt (OIB) are from White and Duncan (1996). Data from the Neoproterozoic mafic intrusions and the 735-Ma adakites in the Hannan region are also shown for comparison (Zhao and Zhou $2008 a, 2008 b$ ).

and $\mathrm{Al}_{2} \mathrm{O}_{3} /\left(\mathrm{K}_{2} \mathrm{O}+\mathrm{Na}_{2} \mathrm{O}\right)$ from 1.06 to 1.20 . These geochemical features suggest that they are more likely to be I-type than S-type granites.

I-type granites can also be distinguished from A-type granites by their associated rock types, mineralogy, and bulk-rock chemistry (Bonin 2007). Atype granites are characterized by high $\mathrm{Fe}_{2} \mathrm{O}_{3} / \mathrm{MgO}$ $(>16), \quad\left(\mathrm{Na}_{2} \mathrm{O}+\mathrm{K}_{2} \mathrm{O}\right) / \mathrm{CaO} \quad(>10), \quad 10000 \mathrm{Ga} / \mathrm{Al}$ $(>2.6)$, and $\mathrm{Zr}+\mathrm{Nb}+\mathrm{Ce}+\mathrm{Y}$ (>350 ppm; Whalen et al. 1987). However, the rocks from the Tianpinghe pluton have relatively low $\mathrm{Fe}_{2} \mathrm{O}_{3} / \mathrm{MgO}$ (2.08-3.75), $\left(\mathrm{Na}_{2} \mathrm{O}+\mathrm{K}_{2} \mathrm{O}\right) / \mathrm{CaO}$ (3.41-9.39), and $10000 \mathrm{Ga} / \mathrm{Al}$ ratios (1.84-2.18). They also have low concentrations of high-field-strength elements and REEs. Their $\mathrm{Nb}$ contents range from 9.27 to $14.3 \mathrm{ppm}$, their $\mathrm{Zr}$ from 170 to $236 \mathrm{ppm}$, and their $\mathrm{Zr}+\mathrm{Nb}+\mathrm{Ce}+\mathrm{Y}$ from 258 to $346 \mathrm{ppm}$. These geochemical compositions are significantly different from those of A-type granites but similar to those of I-type granites (Whalen et al. 1987). The Tianpinghe granites have less than $1 \mathrm{wt} \%$ normative corundum and have slightly negative $\varepsilon \mathrm{Nd}$ $(+0.15$ to -1.76$)$ and positive zircon $\varepsilon \mathrm{Hf}$ values $(+0.6$ to +8.3$)$. Therefore, the rocks from the Tianpinghe pluton are interpreted as I-type granites, as defined by Chappell and White (2001).

Origin of the Tianpinghe Pluton. Calc-alkaline I-type granites can be generated by various pro- cesses. Among these are differentiation of basaltic magmas (e.g., Soesoo 2000), mixing of basaltic magma with felsic crustal components (e.g., Juster et al. 1989; Singer et al. 1992; Kemp et al. 2007), and melting of basaltic crust (e.g., Chappell and White 2001; Wu et al. 2005).

Partial Melting of Ancient Crustal Rocks. The basement of the Yangtze Block is mainly composed of the Paleoproterozoic and Archean rocks (Gao et al. 1999; Qiu et al. 2000; Zhang et al. 2006a, 2006b; Zheng et al. 2006). The Archean rocks, i.e., the Kongling Terrane, consist of dioritic-tonalitictrondhjemitic and granitic gneiss (DTTG), metapelite, and amphibolite. Both whole-rock Nd model ages and zircon $\mathrm{U}-\mathrm{Pb}$ dating reveal several episodes of crustal growth in this terrane from 3.8 to $3.2 \mathrm{Ga}$ (Gao et al. 1999; Qiu et al. 2000; Zhang et al. 2006a, 2006b). Multistage episodic reworking of the Archean crust occurred during the Paleoproterozoic to Neoproterozoic (Zhang et al. 2006b). It is therefore possible that the Tianpinghe granitic pluton represents one episode of reworking of the Yangtze basement.

As discussed in "Analytical Results," the Tianpinghe granites have a narrow range of chemical compositions and relatively constant $\varepsilon \mathrm{Nd}$ values that are much higher than the negative $\varepsilon \mathrm{Nd}$ values

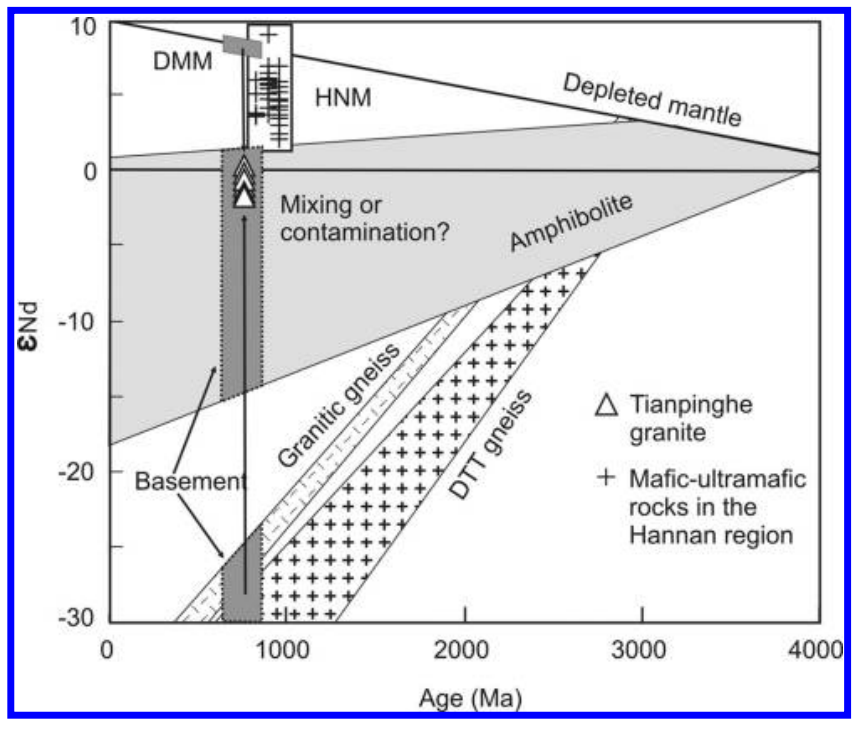

Figure 6. Plots of $\varepsilon \mathrm{Nd}$ versus age $(\mathrm{Ma})$ of rocks from the Tianpinghe pluton. The Nd isotopic evolutionary field for the Archean amphibolite, granitic gneiss, and dioritictonalitic-trondhjemitic gneiss $(D T T)$ at the northern margin of the Yangtze Block are from Gao et al. (1999). The depleted-mantle $(D M M)$ evolution curve is from Goldstein et al. (1984). The $\varepsilon \mathrm{Nd}$ values for the mafic rocks from the Hannan region (HNM) are from Zhou et al. (2002a) and Zhao and Zhou (2008b). 


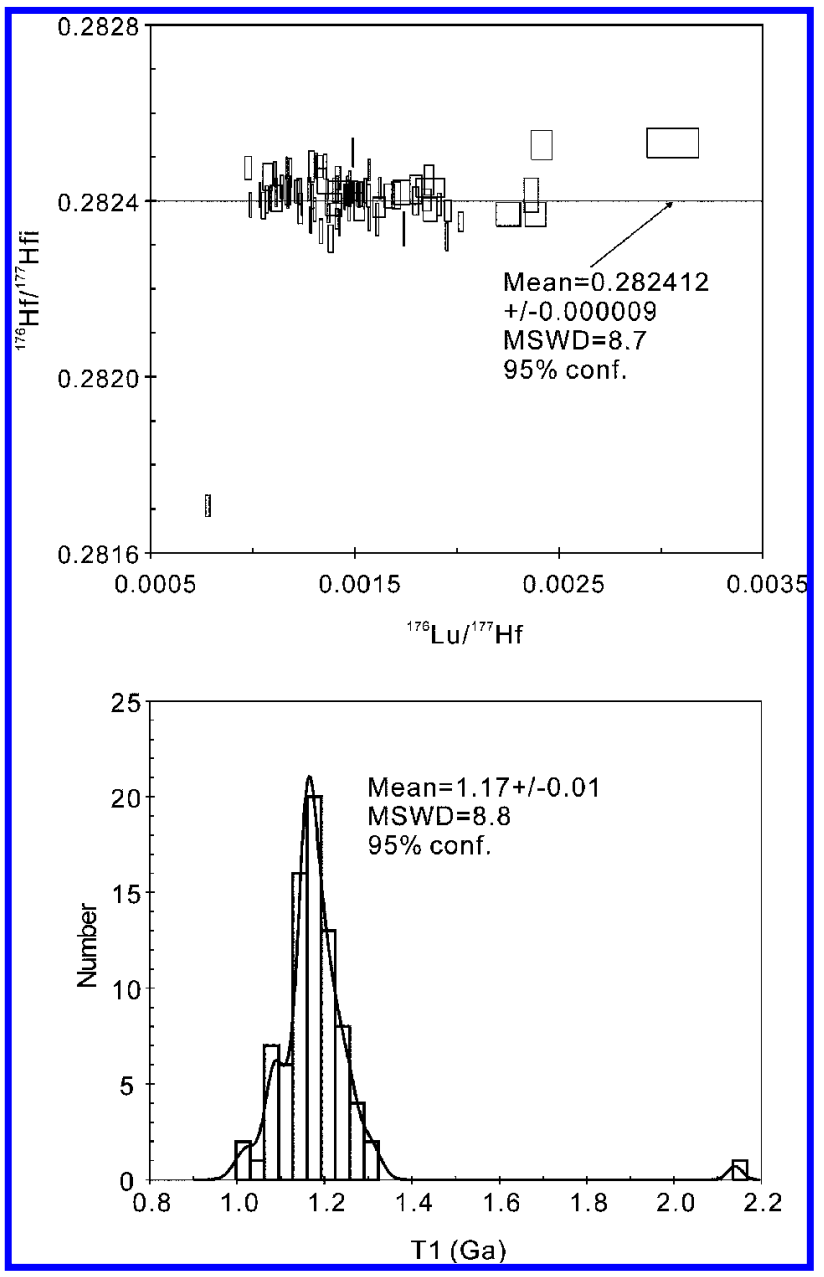

Figure 7. ${ }^{176} \mathrm{Lu} /{ }^{177} \mathrm{Hf}$ versus initial ${ }^{176} \mathrm{Hf} /{ }^{177} \mathrm{Hf}($ top $)$ and histogram of single-stage model Hf ages (bottom) for rocks from the Tianpinghe pluton in the Hannan region, South China.

(as low as -25) of the DTTG (fig. 6), suggesting that they were not produced by partial melting of the DTTG. Although the Tianpinghe granites plot within the upper amphibolite field (fig. 6), they have initial ${ }^{176} \mathrm{Hf} /{ }^{177} \mathrm{Hf}$ ratios higher than those of the basement rocks of the Yangtze Block, further suggesting that the Tianpinghe granites were not produced by partial melting of the Archean rocks (fig. 8). In addition, they have $\mathrm{Cr} / \mathrm{Th}$ ratios (0.040.64) lower than those of the Archean basement rocks $(\mathrm{Cr} / \mathrm{Th}=0.3-33.4$; Gao et al. 1999; fig. 9), essentially eliminating the basement rocks as precursors.

Involvement of Mantle-Derived Magmas. It is generally accepted that I-type granites can be produced by differentiation of mafic magmas (White and Chappell 1977; Eggins and Hensen 1987; Soesoo 2000). Neoproterozoic mafic-ultramafic in- trusive and extrusive rocks are widely distributed in the Hannan region (Zhou et al. 2002a; Ling et al. 2003). These contemporaneous mafic rocks are the only mantle-derived materials that could possibly represent the protolith of the Tianpinghe granites (fig. 1). However, there are significant compositional gaps between the Tianpinghe granites and the mafic rocks. The rocks from the Tianpinghe pluton have relatively high and uniform $\mathrm{SiO}_{2}$ contents $(67-70 \mathrm{wt} \%)$, and their incompatible-traceelement ratios, such as $\mathrm{Cr} / \mathrm{Th}(0.04-0.64), \mathrm{Sm} / \mathrm{Nd}$ $(0.17-0.20)$, and $\mathrm{Sr} / \mathrm{Ba}(0.27-0.39)$, are very different from those of the mafic plutons $/ \mathrm{Cr} / \mathrm{Th}=0.67-$ 11,$600 ; \quad \mathrm{Sm} / \mathrm{Nd}=0.2-0.38 ; \quad \mathrm{Sr} / \mathrm{Ba}=0.61-47.3$; fig. 9). In order to illustrate the trace-element variation relative to fractional crystallization, $\mathrm{Sm}, \mathrm{La}$, Th, and Sc were used to model fractional crystallization. The results show that fractional crystallization of mafic magmas cannot explain the high $\mathrm{La}$ and Th concentrations of the Tianpinghe granites. For example, the values of $\mathrm{La}$ and $\mathrm{Th}$ for the Tianpinghe granites (fig. 10) cannot be reached even with $80 \%$ removal of any mafic mineral from the assumed parental magma. Alternatively, fractional crystallization of mineral assemblage, including olivine, orthopyroxene, clinopyroxene, alkaline feldspar, and plagioclase, may have evolved the mafic parental magma into the Tianpinghe granite. Removal of plagioclase and alkaline feldspar increase Sc but does not modify Th, whereas fractional crystallization of mafic minerals strongly decreases Sc and slightly increases Th (fig. 10). Olivine is the strongest incompatible mineral among the mafic minerals (table 5); therefore, fractional crystallization of olivine is more effective for increasing Th in the melt than is the fractional crystallization of the mineral assemblage of variable proportions. After removal of $80 \%$ of olivine, Th in the melt is lower than that in the Tianpinghe granites. Thus, the Tianpinghe pluton was not generated by simple fractionation of mafic magma.

Alternatively, the I-type granites may have been generated by crustal contamination or mixing of mafic magma with crustally derived felsic magma (e.g., Lackey et al. 2005; Kemp et al. 2007). Granites generated by these processes are normally characterized by abundant mafic enclaves and a wide range of chemical compositions (e.g., Chappell 1996; Janousek et al. 2004). The granitic rocks from the Tianpinghe pluton have $\mathrm{SiO}_{2}$ contents much higher and $\varepsilon \mathrm{Nd}$ values $(+0.15$ to -1.76$)$ notably lower than those of the mafic rocks $(\varepsilon \mathrm{Nd}=$ 3.5-5.9; figs. 5, 6), suggesting that voluminous crustal assimilation would have been required to produce their high $\mathrm{SiO}_{2}$. However, their narrow 


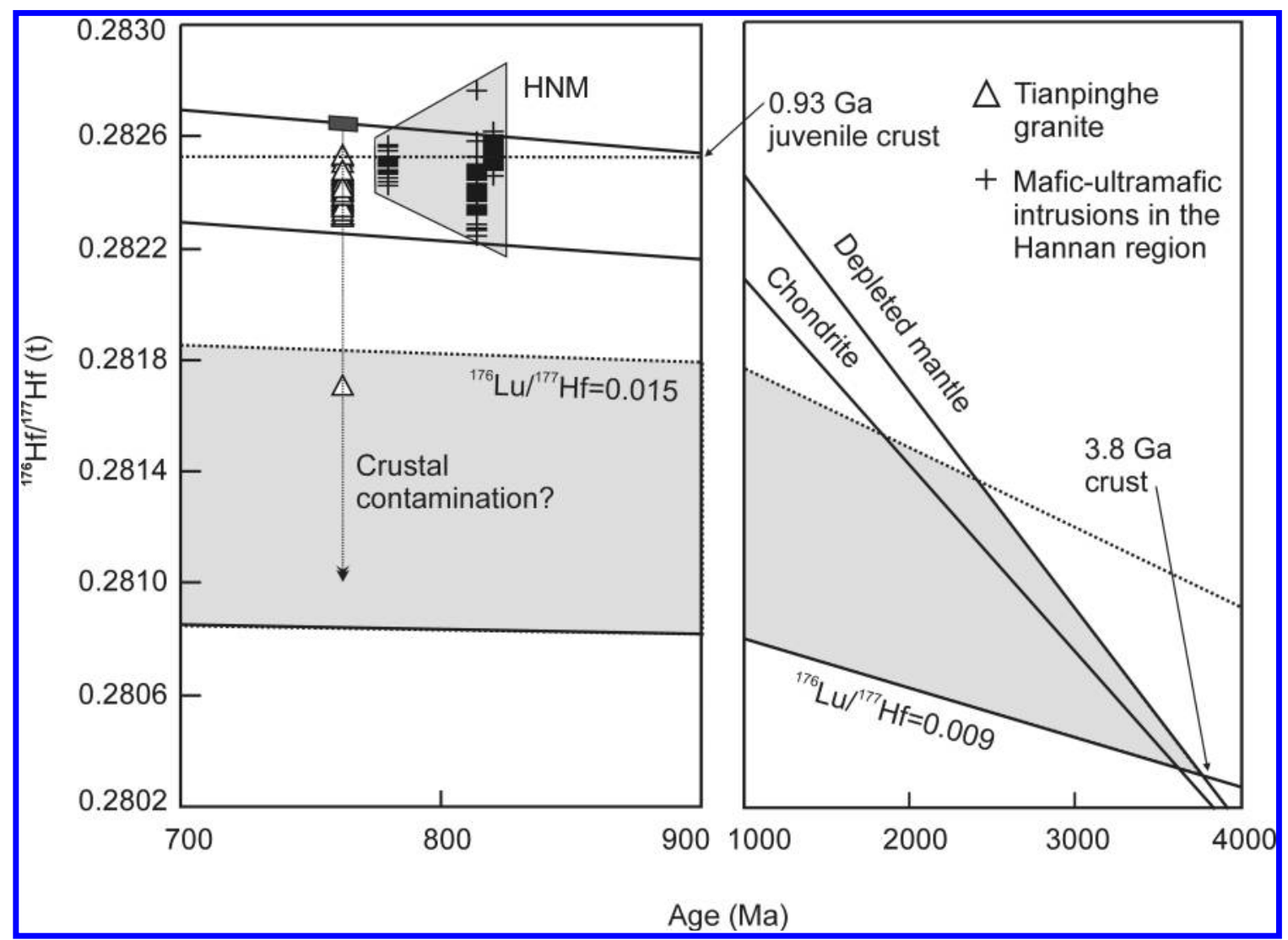

Figure 8. Initial $\mathrm{Hf}$ isotopic compositions at the crystallization age of the zircons for the Tianpinghe granites. Reference lines representing meteoritic Hf evolution and depleted mantle are from Blichert-Toft and Albarede (1997) and Griffin et al. (2000), respectively. The basement of the Yangtze Block is defined on the basis of zircon Hf isotopes for the Precambrian strata (Zhang et al. 2006a, 2006b) and the felsic granulite xenolith from Mesozoic volcanic rocks (Zheng et al. 2006) at assumed ${ }^{176} \mathrm{Lu} /{ }^{177} \mathrm{Hf}$ ratios of 0.015 and 0.009 , respectively. The initial ${ }^{176} \mathrm{Hf} /{ }^{177} \mathrm{Hf}$ ratios for the Neoproterozoic mafic-ultramafic plutons in the Hannan region (HNM) are also shown for comparison (Zhao and Zhou 2008b).

range of $\mathrm{SiO}_{2}$ and $\varepsilon \mathrm{Nd}$ values (figs. 3, 5) and the similar initial ${ }^{176} \mathrm{Hf} /{ }^{177} \mathrm{Hf}$ ratios of their zircons and the mafic rocks in the region (fig. 8) suggest that only minor crustal material was involved in their petrogenesis. Therefore, mafic magma differentiation, crustal contamination, and magma mixing cannot explain the geochemical features of the Tianpinghe pluton.

Partial Melting of Newly Formed Mafic Crust. Melting of basaltic rocks is another way in which I-type granitic magmas may be formed (Chappell and White 2001). The Tianpinghe granites have a minimum single-source-region age of $0.93 \mathrm{Ga}$, defined by the intersection between the depleted-mantle curve and the dashed horizontal line in figure $8\left({ }^{176} \mathrm{Lu} /{ }^{177} \mathrm{Hf}=0\right)$. The rocks from the Tianpinghe pluton have single- and two-stage model ages of 1.01-1.31 and 1.31-2.01 Ga, respectively (table 4). With minor crustal contamination taken into consideration, the youngest two-stage model age of the $1.31 \mathrm{Ga}$ represents the maximum resident time of their source rocks, suggesting that the Tianpinghe granites were more likely produced by melting of newly formed mafic rocks.

In the Hannan region, Neoproterozoic mafic intrusions with ages of $780-820 \mathrm{Ma}$ (Zhou et al. 2002a) are common. Thus, it is possible that the Tianpinghe granites were produced by melting of mafic rocks geochemically similar to these mafic intrusions. An experiment of metabasalt dehydration melting reveals that the silicon concentration of melt decreases with an increasing degree of partial melting (Rapp and Watson 1995). A low degree of melting $(<10 \%)$ produces melts that are highly silicic (Rapp and Watson 1995). To model such a melting process, we use the Neoproterozoic mafic-ultramafic rocks as the parental source of the Tianpinghe pluton (table 5). The source mineralogy 


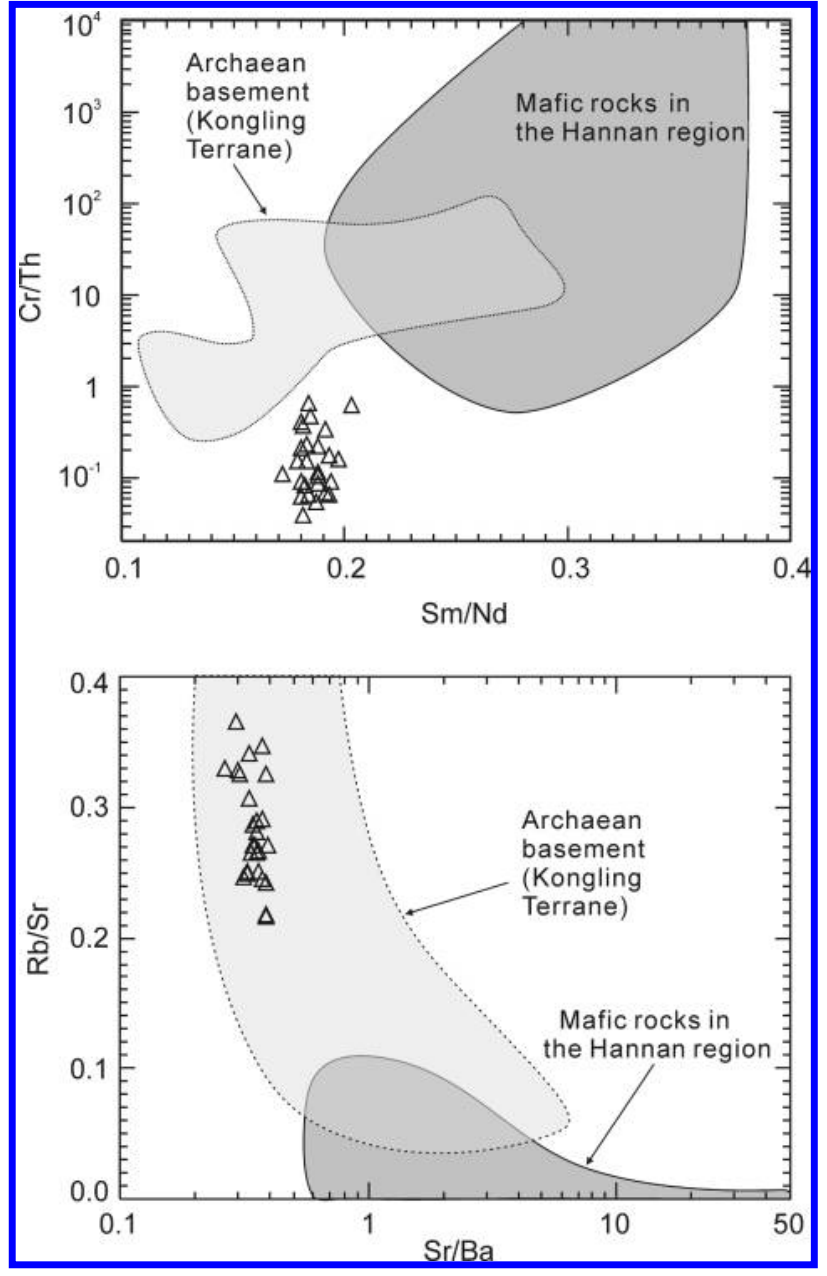

Figure 9. $\mathrm{Sm} / \mathrm{Nd}$ versus $\mathrm{Cr} / \mathrm{Th}($ top $)$ and $\mathrm{Sr} / \mathrm{Ba}$ versus $\mathrm{Rb} / \mathrm{Sr}$ (bottom) for rocks from the Tianpinghe pluton. Neoproterozoic mafic rocks (Zhou et al. 2002a; Zhao and Zhou 2008b) and the Archean basement (Gao et al. 1999) are also shown for comparison.

is obtained from the CIPW calculation of the average bulk-rock compositions of the Bijigou, Wangjiangshan, and Beiba mafic plutons (fig. 1). Traceelement concentrations of the source region are obtained from the average concentrations in these three plutons. Calculation procedures and partition coefficients used for trace-element modeling are given in table 5 . Batch melting calculations reveal that less than $5 \%$ partial melting of the mafic rocks will produce a melt with a chemical composition equivalent to that of the Tianpinghe pluton (fig. 10). The mantle-normalized trace-element patterns (fig. 11) also suggest that $5 \%$ melting of mafic rocks could have produced the Tianpinghe granites. Therefore, we suggest that the Tianpinghe granites were formed by low-percentage melting of newly emplaced mafic rocks.
The rocks from the Tianpinghe pluton have $\varepsilon \mathrm{Nd}$ values slightly lower than those of the Neoproterozoic mafic rocks (fig. 5), suggesting minor

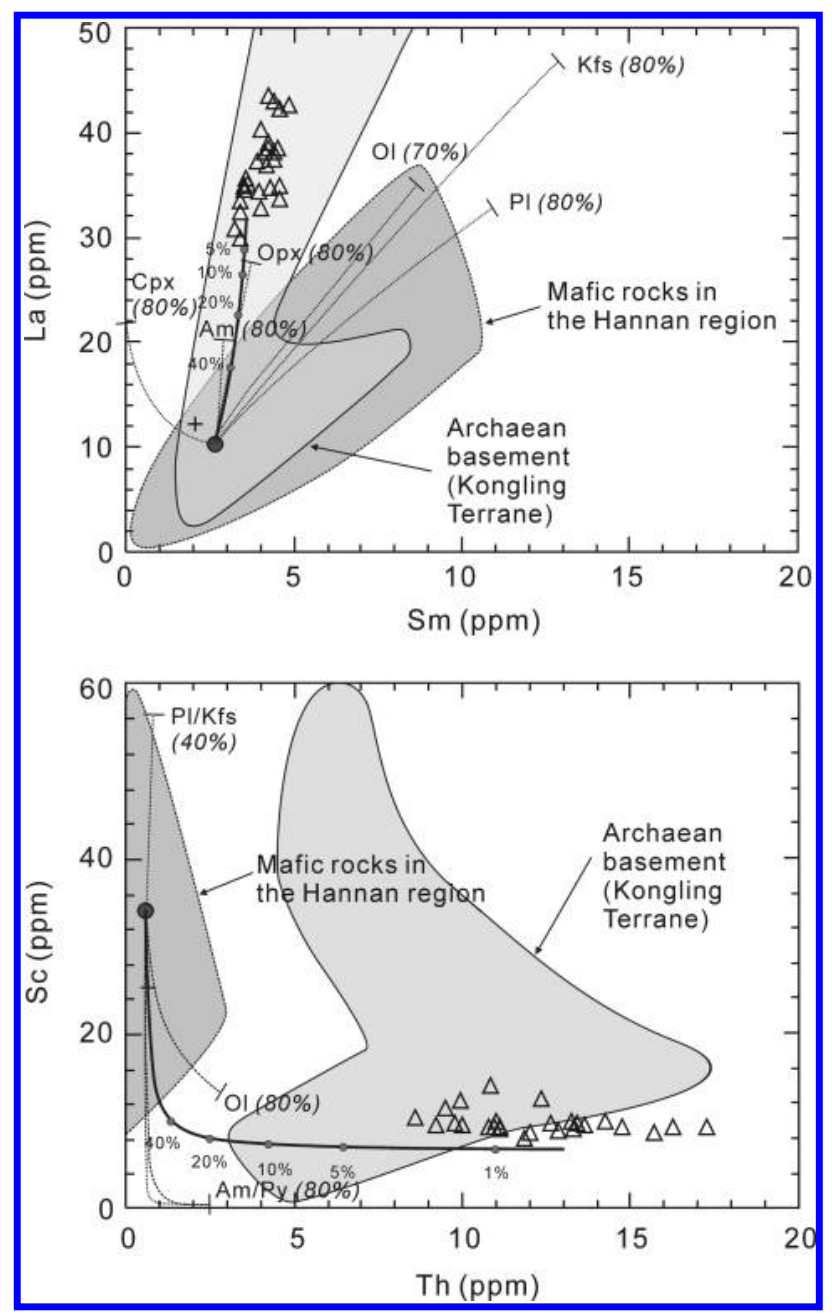

Figure 10. Sm versus $\mathrm{La}(\mathrm{top})$ and Th versus Sc (bottom) for the rocks from the Tianpinghe pluton. Data for mafic rocks from the Neoproterozoic intrusions in the Hannan region are from Zhou et al. (2002a) and Zhao and Zhou (2008b). Data for the Archean basement, represented by the Kongling Terrane, are from Gao et al. (1999). The thick lines represent partial-melting curves for the average compositions of the mafic rocks in the Hannan region and are drawn according to table 5 , and the numbers along the curves are percentages of partial melting. The thin dashed lines represent calculated trends of fractional crystallization. Numbers in parentheses represent the degree of mineral fractionation. Rayleigh fractionation $C_{\mathrm{L}} / C_{\mathrm{O}}=F^{D-1}$ is used, where $C_{\mathrm{L}}$ is concentration of a trace element in the liquid, $C_{\mathrm{O}}$ is concentration of a trace element in the parental liquid, $F$ is the fraction of melt remaining, and $D$ is the partitioning coefficient. Values of $D$ for amphiboles are collectively from Villemant et al. (1981) and Higuchi and Nagasawa (1969); D data for other minerals are shown in table 5. 
Table 5. Trace Elements Used in the Modeling

\begin{tabular}{|c|c|c|c|c|c|c|c|c|}
\hline & Th & $\mathrm{La}$ & $\mathrm{Ce}$ & $\mathrm{Nd}$ & $\mathrm{Sm}$ & $\mathrm{Tb}$ & $\mathrm{Yb}$ & $\mathrm{Lu}$ \\
\hline \multicolumn{9}{|l|}{ Partitioning coefficient $D:^{a}$} \\
\hline Anorthite & .01 & .3 & .22 & .19 & .12 & .14 & .1 & .1 \\
\hline Albite/orthoclase ${ }^{\mathrm{b}}$ & .02 & .07 & .02 & .03 & .02 & .01 & .03 & .02 \\
\hline Clinopyroxene & .1 & .52 & .84 & 1.4 & 2.9 & 3.8 & 3 & 3 \\
\hline Orthopyroxene & .14 & .4 & .46 & .6 & .78 & .85 & .91 & .9 \\
\hline Olivine $^{c}$ & .01 & .1 & .1 & .1 & .1 & .1 & .35 & .44 \\
\hline Apatite & 2 & 20 & 35 & 57 & 63 & 54 & 24 & 20 \\
\hline Ilmenite & .1 & .01 & .01 & .01 & .01 & .01 & .01 & .01 \\
\hline Magnetite & .01 & .66 & .71 & 93 & 1.2 & 1.3 & .44 & .3 \\
\hline \multicolumn{9}{|l|}{ Composition (ppm): } \\
\hline Initial $^{\mathrm{d}}$ & .6 & 10.5 & 21.1 & 10.5 & 2.67 & .47 & 1.41 & .22 \\
\hline \multicolumn{9}{|l|}{ Under partial melting: ${ }^{\mathrm{e}}$} \\
\hline $1 \%$ & 11 & 31.19 & 53.27 & 18.94 & 3.55 & .57 & 1.64 & .36 \\
\hline $5 \%$ & 6.47 & 28.89 & 50.18 & 18.34 & 3.5 & .56 & 1.63 & .35 \\
\hline $10 \%$ & 4.27 & 26.45 & 46.78 & 17.65 & 3.45 & .55 & 1.61 & .34 \\
\hline $20 \%$ & 2.54 & 22.63 & 41.21 & 16.41 & 3.34 & .54 & 1.59 & .32 \\
\hline $30 \%$ & 1.81 & 19.77 & 36.82 & 15.33 & 3.24 & .53 & 1.56 & .3 \\
\hline $40 \%$ & 1.41 & 17.56 & 33.28 & 14.38 & 3.14 & .52 & 1.54 & .29 \\
\hline
\end{tabular}

a Partitioning coefficients are from Bacon and Druitt (1988), except as noted.

${ }^{\mathrm{b}}$ Partitioning coefficients for albite and orthoclase are assumed to be same and are from Nash and Crecraft (1985).

${ }^{c}$ Partitioning coefficients for olivine are from Mahood and Hildreth (1983), Villemant (1988), and Mahood and Stimac (1990).

${ }^{d}$ The Neoproterozoic mafic plutons are assumed to be a protolith of the Tianpinghe granites. Initial trace-element concentrations reflect the average composition of the rocks from the Neoproterozoic mafic plutons exposed in the Hannan region (Zhou et al. 2002a; Zhao and Zhou 2008b).

e Batch partial melting model is calculated by $C_{\mathrm{L}} / C_{\mathrm{O}}=1 /\left[D_{\mathrm{O}}+F\left(1-D_{\mathrm{O}}\right)\right]$, where $C_{\mathrm{L}}$ is the weight concentration of a trace element in the liquid, $C_{\mathrm{O}}$ is the weight concentration of a trace element in the original unmelted solid, $D_{\mathrm{O}}$ is the bulk distribution coefficient of the original solids, and $F$ is the fraction of melt already removed from the source. The source model is $39.2 \%$ anorthite, $26.6 \%$ albite, $2.6 \%$ orthoclase, $12.2 \%$ clinopyroxene, $9.3 \%$ orthopyroxene, $6.7 \%$ olivine, $0.4 \%$ apatite, $1.7 \%$ ilmenite, and $1.3 \%$ magnetite, the CIPW mineral proportions of the average bulk compositions of the mafic rocks (Zhou et al. 2002a; Zhao and Zhou 2008b).

involvement of old crustal material during emplacement. One zircon analysis has an exceptionally low $\varepsilon$ Hf value of -20 , which plots in the field of the basement of the Yangtze Block (fig. 8). Its old single- $(2.14 \mathrm{Ga})$ and two-stage model ages $(3.92 \mathrm{Ga})$ indicate that the zircon is a relict of Archean crustal material. The basement rocks have high Hf concentrations and low ${ }^{177} \mathrm{Hf} /{ }^{176} \mathrm{Hf}$ values (Zhang et al. 2006a, 2006b; Zheng et al. 2006; fig. 8), so that the addition of small amounts of old crustal material can significantly lower the ${ }^{177} \mathrm{Hf} /{ }^{176} \mathrm{Hf}$ ratio of the magma. The variable $\varepsilon$ Hf values $(+0.6$ to +8.3$)$ of zircons from the Tianpinghe pluton suggest that assimilation of old crust played an important role in determining the magma composition. The highest $\varepsilon \mathrm{Hf}$ value of +8.3 may represent the initial $\varepsilon \mathrm{Hf}$ value of the melts, whereas the lowest $\varepsilon \mathrm{Hf}$ value of +0.6 reflects contamination by older crustal components.

Implications for Neoproterozoic Arc-Related Magmatism. Zircon saturation temperatures calculated from bulk-rock compositions provide minimum estimates of initial magma temperature at the source (Miller et al. 2003). The Tianpinghe granites have $\mathrm{Zr}$ contents ranging from 170 to $237 \mathrm{ppm}$, corresponding to zircon saturation temperatures of about $1050^{\circ}-1080^{\circ} \mathrm{C}$ (Miller et al. 2003). This conclusion is consistent with experimental results showing that tonalitic to granitic calc-alkaline magmas are normally generated by dehydration melting of fertile portions of the continental crust at temperatures above $780^{\circ} \mathrm{C}$ (e.g., Rapp 1995; Rapp and Watson 1995). Anatexis of continental crust under temperatures in excess of $780^{\circ} \mathrm{C}$ within continental collision zones requires advective input of heat from the mantle (e.g., Huppert and Sparks 1988; Roberts and Clemens 1993; Miller et al. 2003) accompanied by slow exhumation (Patino and McCarthy 1998). Such high temperatures are generally considered to have occurred in the deep crust and to have required significant heat input through under- or intraplating by mantle-derived basaltic magmas (e.g., Clemens 1990; Vielzeuf et al. 1990). Intraplating of basaltic magmas is thought to be responsible for the melting of refractory mafic rocks by fluid-absent breakdown to produce hot, waterundersaturated, calc-alkaline silicic magmas in an active continental margin. The 762-Ma Tianpinghe 


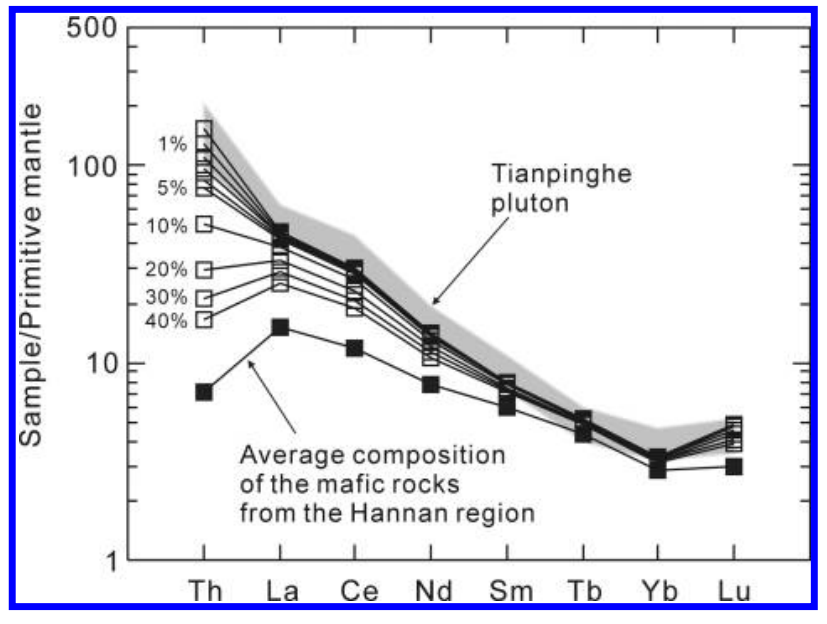

Figure 11. Primitive-mantle-normalized patterns for selected modeled trace elements. The gray area represents the field of the rocks from the Tianpinghe pluton. The numbers represent percentages of partial melting. Normalizing values are from Sun and McDonough (1989).

pluton was generated at a time when the lithospheric mantle was hot, suggesting that intraplating and underplating of mantle-derived magmas were the main heat sources for generating the Tianpinghe pluton.

The 735-Ma adakitic plutons in the Hannan region are explained by melting of a thickened lower mafic crust (Zhao and Zhou 2008a). This mechanism requires that the crust be more than $50 \mathrm{~km}$ thick, the minimum depth for producing adakitic melts in the eclogitized lower crust (e.g., Rapp et al. 1991; Kay and Kay 2002). No older adakitic plutons have been found in the region, suggesting that the thickness of the continental crust gradually increased to more than $50 \mathrm{~km}$ at around $735 \mathrm{Ma}$ by underplating of the mantlederived magma (Zhao and Zhou 2008a). The rocks from the 762-Ma Tianpinghe pluton all plot within the volcanic-arc granite field in the $\mathrm{Nb}$ versus $\mathrm{Y}$ and $\mathrm{Rb}$ versus $\mathrm{Y}+\mathrm{Nb}$ diagrams (fig. 12, VAG), indicating that they were formed in a collisional environment. The Tianpinghe pluton was therefore the product of continental crustal differentiation that resulted from crustal thickening at an active continental margin during the Neoproterozoic (fig. 13).

According to the arc signatures of the Xixiang volcanic rocks in the Hannan region, subduction of oceanic lithosphere beneath the western margin of the Yangtze Block started no later than $950 \mathrm{Ma}$ (Ling et al. 2003). The mafic-ultramafic intrusions in the Hannan region have SHRIMP zircon U-Pb ages ranging from 820 to $746 \mathrm{Ma}$ and show arclike geochemical compositions, suggesting that they were produced by partial melting of a mantle wedge above a subduction zone (Zhou et al. 2002a). In addition to the Tianpinghe granites, I-type calcalkaline Neoproterozoic granites are widely distributed in the western margin of the Yangtze Block (Ling et al. 2001; Zhou et al. 2002b; Chen et al. 2005). Subduction is therefore a reasonable explanation for the long span of arc magmatic activities. The active continental margin persisted for more than 200 m.yr. along this margin, an environment similar to the eastern margin of the Eurasian continent above the subduction zone of the Izanagi/ Pacific oceanic plate since the Triassic (Maruyama et al. 1997).

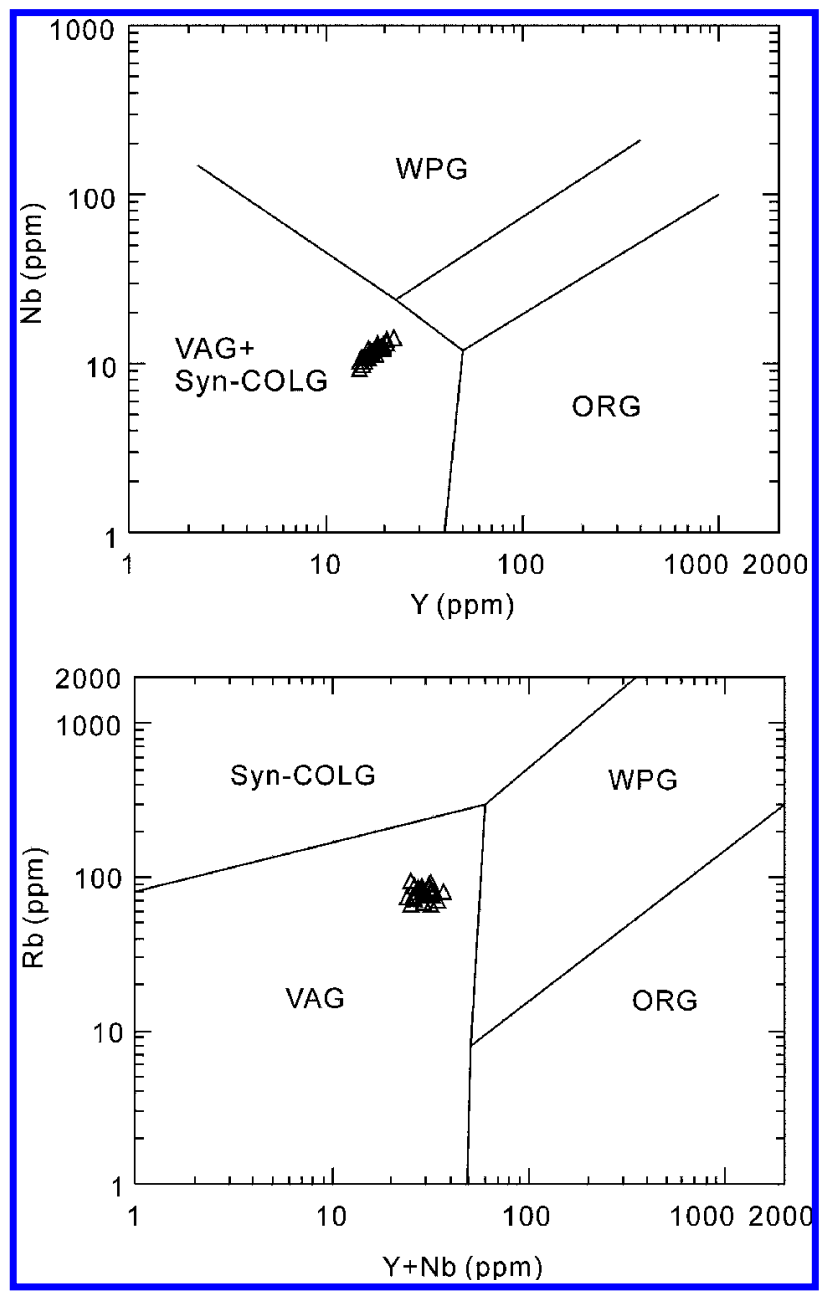

Figure 12. $\mathrm{Nb}$ versus $\mathrm{Y}($ top $)$ and $\mathrm{Rb}$ versus $\mathrm{Y}+\mathrm{Nb}$ (bottom) discrimination diagrams for the Tianpinghe granites, showing the tectonic classification suggested by Pearce et al. (1984). Syn-COLG= syncollisional granite; $V A G=$ volcanic-arc granite; $W P G=$ within-plate granite; $O R G=$ ocean ridge granite. 


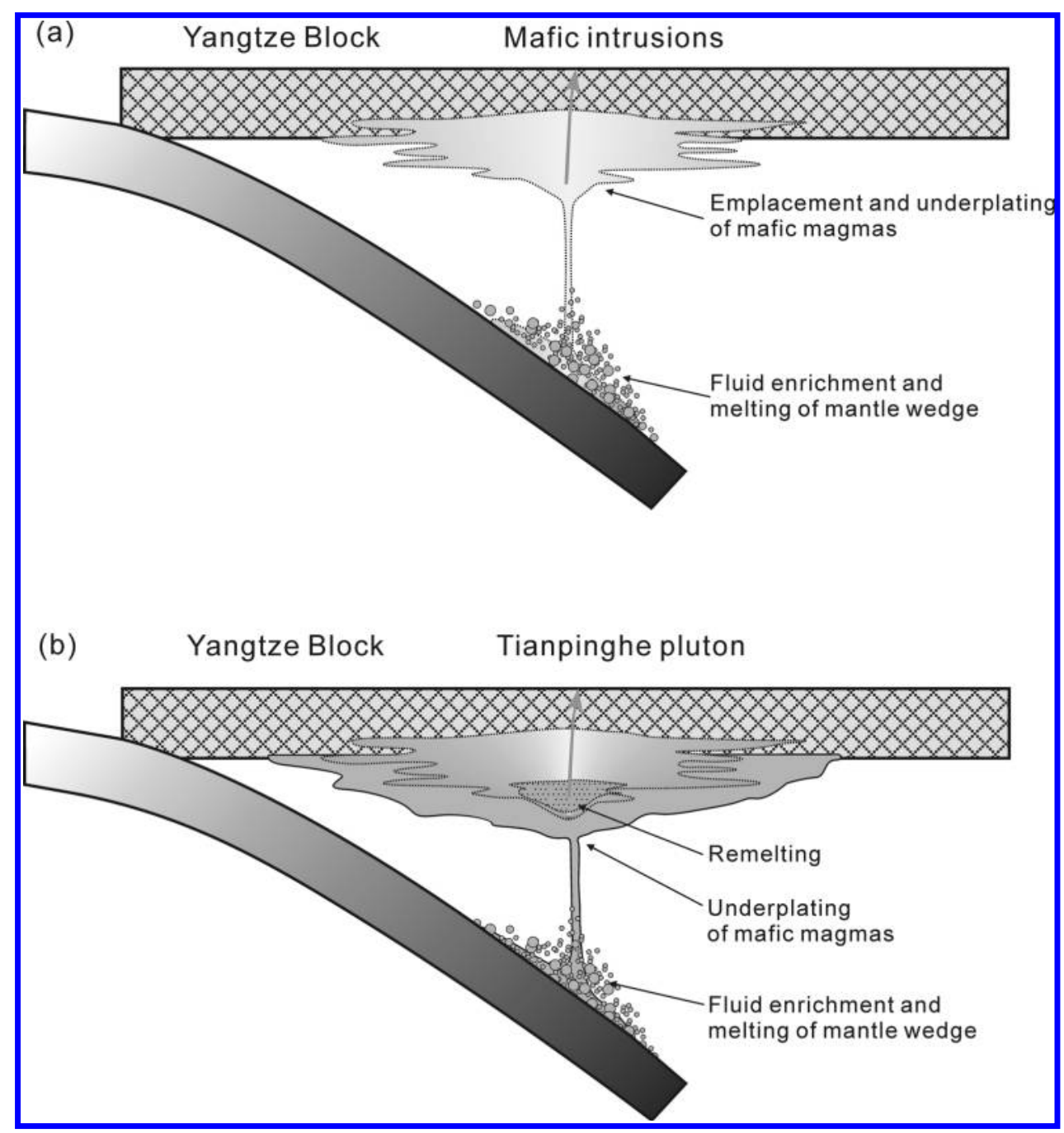

Figure 13. Sketch cross section showing the formation process of the Tianpinghe pluton in the northwestern margin of the Yangtze Block. a, Starting at least at $950 \mathrm{Ma}$, melting of a mantle wedge above a subduction zone resulted in the formation of gabbroic intrusions and magma underplating. $b$, Intraplating melts of the newly formed basaltic rocks at less than $50 \mathrm{~km}$ produced the Tianpinghe granites. This two-stage model suggests that the Neoproterozoic was an important stage of continental crustal growth and differentiation in the northwestern margin of the Yangtze Block.

The presence of a long-lived magmatic arc, the socalled Panxi-Hannan arc (Zhou et al. 2002b), at the western margin of the Yangtze Block rules out the Rodinian-reconstruction model proposed by Li et al. (2003), in which South China was located in the center of the supercontinent. Instead, the PanxiHannan arc may have been part of the Neoproterozoic Andean-type arc that has been defined by volcanic and plutonic rocks in Madagascar, Seychelles, and northwestern India (Tucker et al. 2001). Therefore, South China was most probably located along the margin of the Neoproterozoic supercontinent (Zhou et al. 2006a). The Neoproterozoic granites at the western margin of the Yangtze Block are part of the Andean-type arc assemblage at the northwestern margin of Rodinia.

\section{Conclusions}

The rocks from the 762-Ma Tianpinghe pluton are I-type granites that were generated by partial melting of newly formed basaltic rocks in the lower crust. This mafic lower crust formed by intraplating of mantle-derived magma during crustal thickening. The Neoproterozoic was an important period of continental growth and reworking in the Yangtze 
Block. The northwestern margin of the Yangtze Block was an active continental arc for a period of 200 m.yr., similar to the present-day eastern margin of the Eurasian continent. Reworking of the newly formed continental crust may have been the main mechanism of crustal differentiation in the Yangtze Block. The long-lasting Neoproterozoic arc at the western margin of the Yangtze Block suggests that it was a continuation of the Andean-type arc at the northwestern margin of the Rodinia.

\section{A C K N O W LEDG M ENTS}

This work was substantially supported by grants from the National Natural Science Foundation of China (40873027), the Chinese Academy of Science (2005), and a Chinese 973 project matching fund from the University of Hong Kong. We are grateful to Allen Kennedy for SHRIMP dating, Xiao Fu for $\mathrm{x}$ ray fluorescence analyses, Gao Jian-Feng for ICPMS analyses, and Liu He and Zhao Xin-Fu for zircon Lu-Hf analyses. Cheng Wei is also thanked for his assistance in the field.

\section{R E F E R E N C E S C I T E D}

Bacon, C. R., and Druitt, T. H. 1988. Compositional evolution of the zoned calc-alkaline magma chamber of Mount Mazama, Crater Lake, Oregon. Contrib. Mineral. Petrol. 98:224-256.

Blichert-Toft, J., and Albarede, F. 1997. The Lu-Hf geochemistry of chondrites and the evolution of the mantle-crust system. Earth Planet. Sci. Lett. 148: 243-258.

Bonin, B. 2007. A-type granites and related rocks: evolution of a concept, problems and prospects. Lithos 97: $1-29$.

Bureau of Geology and Mineral Resources of Shanxi Province (BGMRS). 1989. Regional geology of Shan'Xi Province. Beijing, Geological Publishing House.

Chappell, B. W. 1996. Magma mixing and the production of compositional variation within granite suites: evidence from the granites of southeastern Australia. J. Petrol. 37:449-470.

Chappell, B. W., and White, A. J. R. 2001. Two contrasting granite types: 25 years later. Aust. J. Earth Sci. 48: 489-499.

Chen, J. F.; Foland, K. A.; Xing, F. M.; Xu, X.; and Zhou, T. X. 1991. Magmatism along the southeastern margin of the Yangtze block: Precambrian collision of the Yangtze and Cathaysia blocks of China. Geology 19: 815-818.

Chen, Y. L.; Luo, Z. H.; Zhao, J. X.; Li, Z. H.; Zhang, H. F.; and Song, B. 2005. Petrogenesis and dating of the Kangding complex, Sichuan Province. Sci. in China Ser. D Earth Sci. 48:622-634.

Clemens, A. 1990. The granulite-granite connection. In Vielzeuf, D., and Vidal, P., eds. Granulites and crustal evolution. Dordrecht, Kluwer, p. 25-36.

Cluzel, D.; Bosch, D.; Paquette, J.-L.; Lemennicier, Y.; Montjoie, P.; and Ménot, R.-P. 2005. Late Oligocene post-obduction granitoids of New Caledonia: a case for reactivated subduction and slab break-off. Island Arc 14:254-271.

Collins, W. J.; Beams, S. D.; White, A. J. R.; and Chappell, B. W. 1982. Nature and origin of A-type granites with particular reference to southeastern Australia. Contrib. Mineral. Petrol. 80:189-200. $\rightarrow$ Eggins, S., and Hensen, B. J. 1987. Evolution of mantlederived, augite-hypersthene granodiorites by crystalliquid fractionation: Barrington Tops batholith, eastern Australia. Lithos 20:295-310.

$\rightarrow$ Frost, B. R.; Barnes, C. G.; Collins, W. J.; Arculus, R. J.; Ellis, D. J.; and Frost, C. D. 2001. A geochemical classification for granitic rocks. J. Petrol. 42:2033-2048.

$\rightarrow$ Gao, S.; Ling, W. L.; Qiu, Y. M.; Lian, Z.; Hartmann, G.; and Simon, K. 1999. Contrasting geochemical and Sm$\mathrm{Nd}$ isotopic compositions of Archean metasediments from the Kongling high-grade terrain of the Yangtze craton: evidence for cratonic evolution and redistribution of REE during crustal anatexis. Geochim. Cosmochim. Acta 63:2071-2088.

$\rightarrow$ Gao, S.; Zhang, B. R.; and Li, Z. J. 1990. Geochemical evidence for Proterozoic continental arc and continental margin rift magmatism along the northern margin of the Yangtze Craton, South China. Precambrian Res. 47:205-221.

$\rightarrow$ Goldstein, S. L.; O'Nions, R. K.; and Hamilton, P. J. 1984. A Sm-Nd isotopic study of atmospheric dusts and particulates from major rivers systems. Earth Planet. Sci. Lett. 70:221-236.

$\rightarrow$ Greentree, M. R.; Li, Z. X.; Li, X. H.; and Wu, H. C. 2006. Late Mesoproterozoic to earliest Neoproterozoic basin record of the Sibao orogenesis in western South China and relationship to the assembly of Rodinia. Precambrian Res. 151:79-100.

$\rightarrow$ Griffin, W. L.; Pearson, N. J.; Belousova, E.; Jackson, S. E.; van Achterberg, E.; O'Reilly, S. Y.; and Shee, S. R. 2000. The Hf isotope composition of cratonic mantle: LAMMC-ICPMS analysis of zircon megacrysts in kimberlites. Geochim. Cosmochim. Acta 64:133-147.

$\rightarrow$ Higuchi, H., and Nagasawa, H. 1969. Partition of trace elements between rock-forming minerals and the host volcanic rocks. Earth Planet. Sci. Lett. 7:281-287.

Hsü, K. J.; Wang, Q. C.; Li, J. L.; Zhou, D.; and Sun, S. 1987. Tectonic evolution of Qinling Mountains, China. Eclogae Geol. Helv. 80:735-753.

Huppert, H. E., and Sparks, R. S. J. 1988. The generation of granitic magmas by intrusion of basalt into continental crust. J. Petrol. 29:599-624. 
Janousek, V.; Braithwaite, C. J. R.; Bowes, D. R.; and Gerdes, A. 2004. Magma-mixing in the genesis of Hercynian calc-alkaline granitoids: an integrated petrographic and geochemical study of the Sazava intrusion, Central Bohemian Pluton, Czech Republic. Lithos 78: 67-99.

$\rightarrow$ Juster, T. C.; Grove, T. L.; and Perfit, M. R. 1989. Experimental constraints on the generation of FeTi basalts, andesites, and rhyodacites at the Galapagos Spreading Center, $85^{\circ} \mathrm{W}$ and $95^{\circ} \mathrm{W}$. J. Geophys. Res. 94:9251-9274.

Kay, R. W., and Kay, S. M. 2002. Andean adakites: three ways to make them. Acta Petrol. Sin. 18:303-311.

$\rightarrow$ Kemp, A. I. S.; Hawkesworth, C. J.; Foster, G. L.; Paterson, B. A.; Woodhead, J. D.; Hergt, J. M.; Gray, C. M.; and Whitehouse, M. J. 2007. Magmatic and crustal differentiation history of granitic rocks from Hf-O isotopes in zircon. Science 315:980-983.

$\rightarrow$ Lackey, J. S.; Valley, J. W.; and Saleeby, J. B. 2005. Supracrustal input to magmas in the deep crust of Sierra Nevada batholith: evidence from high- $\delta^{18} \mathrm{O}$ zircon. Earth Planet. Sci. Lett. 235:315-330.

$\rightarrow$ Li, X. H., and McCulloch, M. T. 1996. Secular variation in the $\mathrm{Nd}$ isotopic composition of Neoproterozoic sediments from the southern margin of the Yangtze Block: evidence for a Proterozoic continental collision in south China. Precambrian Res. 76:67-76.

$\rightarrow$ Li, Z. X.; Li, X. H.; Kinny, P. D.; Wang, J.; Zhang, S.; and Zhou, H. 2003. Geochronology of Neoproterozoic synrift magmatism in the Yangtze Craton, South China and correlations with other continents: evidence for a mantle superplume that broke up Rodinia. Precambrian Res. 122:85-109.

$\rightarrow$ Li, Z. X.; Wartho, J. A.; Occhipinti, S.; Zhang, C. L.; Li, X. H.; Wang, J.; and Bao, C. M. 2007. Early history of the eastern Sibao Orogen (South China) during the assembly of Rodinia: new mica ${ }^{40} \mathrm{Ar} /{ }^{39} \mathrm{Ar}$ dating and SHRIMP U-Pb detrital zircon provenance constraints. Precambrian Res. 159:79-94.

$\rightarrow$ Li, Z. X.; Zhang, L.; and Powell, C. M. 1995. South China in Rodinia: part of the missing link between AustraliaEast Antarctica and Laurentia? Geology 23:407-410.

$\rightarrow$ Ling, H. F.; Shen, W. Z.; Wang, R. C.; and Xu, S. J. 2001. Geochemical characteristics and genesis of Neoproterozoic granitoids in the northwestern margin of the Yangtze Block. Phys. Chem. Earth A 26:805-819.

Ling, W. L.; Gao, S.; Cheng, J. P.; Jiang, L. S.; Yuan, H. L.; and $\mathrm{Hu}, \mathrm{Z}$. C. 2006. Neoproterozoic magmatic events within the Yangtze continental interior and along its northern margin and their tectonic implication: constraint from the ELA-ICPMS U-Pb geochronology of zircons from the Huangling and Hannan complexes. Acta Petrol. Sin. 22:387-396.

$\rightarrow$ Ling, W. L.; Gao, S.; Zhang, B. R.; Li, H. M.; Liu, Y.; and Cheng, J. P. 2003. Neoproterozoic tectonic evolution of the northwestern Yangtze craton, South China: implications for amalgamation and break-up of the Rodinia supercontinent. Precambrian Res. 122:111-140.

$\rightarrow$ Mahood, G. A., and Hildreth, E. W. 1983. Large partition coefficients for trace elements in high-silica rhyolites. Geochim. Cosmochim. Acta 47:11-30. $\rightarrow$ Mahood, G. A., and Stimac, J. A. 1990. Trace-element partitioning in pantellerites and trachytes. Geochim. Cosmochim. Acta 54:2257-2276.

$\rightarrow$ Maruyama, S.; Isozaki, Y.; Kimura, G.; and Terabayashi, M. 1997. Paleogeographic maps of the Japanese Islands: plate tectonic synthesis from $750 \mathrm{Ma}$ to the present. Island Arc 6:121-142.

$\rightarrow$ Mattauer, M.; Matte, P.; Malavieille, P.; Tapponnier, P.; Maluski, H.; Xu, Z. Q.; Lu, Y. L.; and Tang, Y. Q. 1985. Tectonics of the Qingling belt: build-up and evolution of eastern Asia. Nature 317:496-500.

Middlemost, E. A. K. 1994. Naming materials in the magma/igneous rock system. Earth Sci. Rev. 37: 215-224.

$\rightarrow$ Miller, C. F.; McDowell, S. M.; and Mapes, R. W. 2003. Hot and cold granites? implications of zircon saturation temperatures and preservation of inheritance. Geology 31:529-532.

$\rightarrow$ Nash, W. P., and Crecraft, H. R. 1985. Partition coefficients for trace elements in silicic magmas. Geochim. Cosmochim. Acta 49:2309-2322.

$\rightarrow$ Ortega-Obregon, C.; Keppie, J. D.; Solari, L. A.; OrtegaGutiérrez, F.; Dostal, J.; Lopez, R.; Ortega-Rivera, A.; and Lee, J. W. K. 2003. Geochronology and geochemistry of the $\sim 917 \mathrm{Ma}$, calc-alkaline Etla granitoid pluton (Oaxaca, southern Mexico): evidence of postGrenvillian subduction along the northern margin of Amazonia. Int. Geol. Rev. 45:596-610.

Patino, D. A. E., and McCarthy, T. C. 1998. Melting of crustal rocks during continental collision and subduction. In Hacker, B. R., and Liou, J. G., eds. When continents collide: geodynamics and geochemistry of ultrahigh-pressure rocks. Petrology and Structural Geology 10. Dordrecht, Kluwer, p. 27-55.

Pearce, J. A.; Harris, N. B. W.; and Tindle, A. G. 1984. Traceelement discrimination diagrams for the tectonic interpretation of granitic rocks. J. Petrol. 25:956-983.

Pitcher, W. S. 1993. The nature and origin of granite. London, Blackie Academic and Professional, $321 \mathrm{p}$.

$\rightarrow$ Qiu, Y. M.; Gao, S.; McNaughton, N. J.; Groves, D. I.; and Ling, W. L. 2000. First evidence of $\geq 3.2$ Ga continental crust in the Yangtze craton of south China and its implications for Archean crustal evolution and Phanerozoic tectonics. Geology 28:11-14.

$\rightarrow$ Rajesh, H. M. 2004. The igneous charnockite-high-K alkali-calcic I-type granite-incipient charnockite association in Trivandrum Block, southern India. Contrib. Mineral. Petrol. 147:346-362.

$\rightarrow$ Rapp, R. P. 1995. Amphibole-out phase boundary in partially melted metabasalt, its control over liquid fraction and composition, and source permeability. J. Geophys. Res. 100:15,601-15,610.

Rapp, R. P., and Watson, E. B. 1995. Dehydration melting of metabasalt at 8-32 kbar: implications for continental growth and crust-mantle recycling. J. Petrol. 36:891-931.

$\rightarrow$ Rapp, R. P.; Watson, E. B.; and Miller, C. F. 1991. Partial melting of amphibolite/eclogite and the origin of Archean trondhjemites and tonalities. Precambrian Res. 51:1-25. 
$\rightarrow$ Roberts, M. P., and Clemens, J. D. 1993. Origin of highpotassium, calc-alkaline, I-type granitoids. Geology $21: 825-828$.

Roberts, M. P.; Pin, C.; Clemens, J. D.; and Paquette, J. L. 2000. Petrogenesis of mafic to felsic plutonic rock associations: the calc-alkaline Quérigut Complex, French Pyrenees. J. Petrol. 41:809-844.

$\rightarrow$ Rudnick, R. L. 1995. Making continental crust. Nature 378:571-578.

$\rightarrow$ Singer, B. S.; Myers, J. S.; and Frost, C. D. 1992. MidPleistocene lavas from the Seguam volcanic center, central Aleutian arc: closed-system fractional crystallization of a basalt to rhyodacite eruptive suite. Contrib. Mineral. Petrol. 110:87-112.

$\rightarrow$ Soesoo, A. 2000. Fractional crystallization of mantlederived melts as a mechanism for some I-type granite petrogenesis: an example from Lachlan Fold Belt, Australia. J. Geol. Soc. Lond. 157:135-149.

$\rightarrow$ Sun, S.-S., and McDonough, W. F. 1989. Chemical and isotopic systematics of oceanic basalts: implications for mantle composition and processes. In Saunders, A. D., and Norry, M. J., eds. Magmatism in the ocean basins. Geol. Soc. Lond. Spec. Publ. 42:313-345.

$\rightarrow$ Tucker, R. D.; Ashwal, L. D.; and Torsvik, T. H. 2001. U-Pb geochronology of Seychelles granitoids: a Neoproterozoic continental arc fragment. Earth Planet. Sci. Lett. 187:27-38.

Vielzeuf, D.; Clemens, J. D.; Pin, C.; and Moinet, E. 1990. Granites, granulites, and crustal differentiation. In Vielzeuf, D., and Vidal, P., eds. Granulites and crustal evolution. Nato ASI Series C-311. Dordrecht, Kluwer, p. 59-85.

$\rightarrow$ Villemant, B. 1988. Trace-element evolution in the Phlegrean Fields (central Italy): fractional crystallization and selective enrichment. Contrib. Mineral. Petrol. 98: 169-183.

$\rightarrow$ Villemant, B.; Jaffrezic, H.; Joron, J.-L.; and Treuil, M. 1981. Distribution coefficients of major and trace elements; fractional crystallization in the alkali basalt series of Chaîne des Puys (Massif Central, France). Geochim. Cosmochim. Acta 45:1997-2016.

$\rightarrow$ Wang, X. L.; Zhou, J. C.; Griffin, W. L.; Wang, R. C.; Qiu, J. S.; O'Reilly, S. Y.; Xua, X. S.; Liu, X. M.; and Zhang, G. L. 2007. Detrital zircon geochronology of Precambrian basement sequences in the Jiangnan orogen: dating the assembly of the Yangtze and Cathaysia blocks. Precambrian Res. 159:117-131.

$\rightarrow$ Whalen, J. B.; Currie, K. L.; and Chappell, B. W. 1987. A-type granites: geochemical characteristics, discrimination and petrogenesis. Contrib. Mineral. Petrol. 95: 407-419.

$\rightarrow$ White, A. J. R., and Chappell, B. W. 1977. Ultrametamorphism and granitoid genesis. Tectonophysics 43: $7-22$.

. 1983. Granitoid types and their distribution in the Lachlan Fold Belt, southeastern Australia. In Roddick, J. A., ed. Circum-Pacific plutonic terranes. Geol. Soc. Am. Mem. 159. Boulder, CO, Geol. Soc. Am., p. 21-34.

White, W. M., and Duncan, R. A. 1996. Geochemistry and geochronology of the Society Islands: new evidence for deep mantle recycling. In Basu, A., and Hart, S. R., eds. Earth processes, reading the isotopic code. Geophysical Monograph 95. Washington, DC, Am. Geol. Union, p. 183-206.

$\rightarrow$ Wu, F. Y.; Yang, J. H.; Wilde, S. A.; and Zhang, X. O. 2005. Geochronology, petrogenesis and tectonic implications of Jurassic granites in the Liaodong Peninsula, NE China. Chem. Geol. 221:127-156.

$\rightarrow$ Yan, D.-P.; Zhou, M.-F.; Song, H.-L.; Wang, X.-W.; and Malpas, J. 2003. Origin and tectonic significance of a Mesozoic multi-layer over-thrust within the Yangtze Block (South China). Tectonophysics 361:239-254.

$\rightarrow$ Yan, Q. R.; Hanson, A. D.; Wang, Z. Q.; Druschke, P. A.; Yan, Z.; Wang, T.; Liu, D. Y.; et al. 2004. Late Proterozoic subduction and rifting on the northern margin of the Yangtze Plate, China: implications for Rodinia reconstruction. Int. Geol. Rev. 46:817-832.

Zhang, R. P. 1991. Geological map of Qingling-Dabie mountains and adjacent region of the People's Republic of China. Beijing, Geological Publishing House, scale $1: 1,000,000$.

$\rightarrow$ Zhang, S. B.; Zheng, Y. F.; Wu, Y. B.; Zhao, Z. F.; Gao, S.; and $\mathrm{Wu}, \mathrm{F}$. Y. 2006a. Zircon isotope evidence for $\geq 3.5 \mathrm{Ga}$ continental crust in the Yangtze craton of China. Precambrian Res. 146:16-34.

$\rightarrow-2006 b$. Zircon U-Pb age and Hf isotope evidence for 3.8 Ga crustal remnant and episodic reworking of Archean crust in South China. Earth Planet. Sci. Lett. 252:56-71.

$\rightarrow$ Zhao, J. H., and Zhou, M.-F. 2007a. Geochemistry of Neoproterozoic mafic intrusions in the Panzhihua district (Sichuan Province, SW China): implications for subduction-related metasomatism in the upper mantle. Precambrian Res. 152:27-47.

$\rightarrow-2007 b$. Neoproterozoic adakitic plutons and arc magmatism along the western margin of the Yangtze Block, South China. J. Geol. 115:675-689.

$\rightarrow-2008 a$. Neoproterozoic adakitic plutons in the northern margin of the Yangtze Block, China: partial melting of a thickened lower crust and implications for secular crustal evolution. Lithos 104:231-248.

- 2008b. Secular evolution of the Neoproterozoic lithospheric mantle underneath the northern margin of the Yangtze Block, South China. Lithos, doi: 10.1016/j.lithos.2008.09.017.

$\rightarrow$ Zheng, J. P.; Griffin, W. L.; O'Reilly, S. Y.; Zhang, M.; Pearson, N.; and Pan, Y. 2006. Widespread Archean basement beneath the Yangtze craton. Geology 34: 417-420.

$\rightarrow$ Zhou, M.-F.; Kennedy, A. K.; Sun, M.; Malpas, J.; and Lesher, C. M. 2002a. Neo-proterozoic arc-related mafic intrusions in the northern margin of South China: implications for accretion of Rodinia. J. Geol. 110:611-618.

$\rightarrow$ Zhou, M.-F.; Ma, Y. X.; Yan, D.-P.; Xia, X. P.; Zhao, J.-H.; and Sun, M. 2006a. The Yanbian Terrane (southern Sichuan Province, SW China): a Neoproterozoic arc assemblage in the western margin of the Yangtze Block. Precambrian Res. 144:19-38. 
$\rightarrow$ Zhou, M.-F.; Yan, D.-P.; Kennedy, A. K.; Li, Y. Q.; and Ding, J. 2002b. SHRIMP zircon geochronological and geochemical evidence for Neoproterozoic arc-magmatism along the western margin of the Yangtze Block, South China. Earth Planet. Sci. Lett. 196: 51-67.

$\rightarrow$ Zhou, M.-F.; Yan, D.-P.; Wang, C.-L.; Qi, L.; and Kennedy, A. 2006b. Subduction-related origin of the $750 \mathrm{Ma}$
Xuelongbao adakitic complex (Sichuan Province, China): implications for the tectonic setting of the giant Neoproterozoic magmatic event in South China. Earth Planet. Sci. Lett. 248:286-300.

immer, M.; Kroner, A.; Jochum, K. P.; Reischmann, T.; and Todt, W. 1995. The Gabal Gerf complex: a Precambrian N-MORB ophiolite in the Nubian Shield, NE Africa. Chem. Geol. 123:29-51. 